\title{
INCLUSIVE COMMUNITY ENERGY RESILIENCE IN BANGLADESH
}

NO. 89

January 2022
ADB SOUTH ASIA WORKING PAPER SERIES 

ADB South Asia Working Paper Series

\section{Inclusive Community Energy Resilience in Bangladesh}

No. 89 | January 2022 
(C) 2022 Asian Development Bank 6 ADB Avenue, Mandaluyong City, 1550 Metro Manila, Philippines

Tel +632 8632 4444; Fax +63286362444

www.adb.org

Some rights reserved. Published in 2022.

ISSN 2313-5867 (print), 2313-5875 (electronic)

Publication Stock No. WPS210522-2

DOI: http://dx.doi.org/10.22617/WPS210522-2

The views expressed in this publication are those of the authors and do not necessarily reflect the views and policies of the Asian Development Bank (ADB) or its Board of Governors or the governments they represent.

ADB does not guarantee the accuracy of the data included in this publication and accepts no responsibility for any consequence of their use. The mention of specific companies or products of manufacturers does not imply that they are endorsed or recommended by ADB in preference to others of a similar nature that are not mentioned.

By making any designation of or reference to a particular territory or geographic area, or by using the term "country" in this document, $A D B$ does not intend to make any judgments as to the legal or other status of any territory or area.

This work is available under the Creative Commons Attribution 3.0 IGO license (CC BY 3.0 IGO)

https://creativecommons.org/licenses/by/3.0/igo/. By using the content of this publication, you agree to be bound by the terms of this license. For attribution, translations, adaptations, and permissions, please read the provisions and terms of use at https://www.adb.org/terms-use\#openaccess.

This CC license does not apply to non-ADB copyright materials in this publication. If the material is attributed to another source, please contact the copyright owner or publisher of that source for permission to reproduce it. $\mathrm{ADB}$ cannot be held liable for any claims that arise as a result of your use of the material.

Please contact pubsmarketing@adb.org if you have questions or comments with respect to content, or if you wish to obtain copyright permission for your intended use that does not fall within these terms, or for permission to use the ADB logo.

The ADB South Asia Working Paper Series is a forum for ongoing and recently completed research and policy studies undertaken in ADB or on its behalf. It is meant to enhance greater understanding of current important economic and development issues in South Asia, promote policy dialogue among stakeholders, and facilitate reforms and development management.

The ADB South Asia Working Paper Series is a quick-disseminating, informal publication whose titles could subsequently be revised for publication as articles in professional journals or chapters in books. The series is maintained by the South Asia Department. The series will be made available on the ADB website and on hard copy.

Corrigenda to ADB publications may be found at http://www.adb.org/publications/corrigenda.

Note:

In this publication, “\$” refers to United States dollars. 
The framework and methodology proposed in this paper were developed and written by Reihana Mohideen and Antonin Demazy of The University of Melbourne, Australia. Priyantha Wijayatunga, director, South Asia Energy Division (SAEN), and Francesco Tornieri, principal social development specialist (gender and development), South Asia Department, led the team in the commissioning and finalization of the paper, with support from Aaron Dennis, social development specialist, SAEN, in coordinating and responding to the peer review process. Tilak Siyambalapitiya, consultant, contributed to align the concept with current priorities for Bangladesh. 



\section{CONTENTS}

TABLES, FIGURES, AND BOXES vii

ABBREVIATIONS viii

$\begin{array}{ll}\text { GLOSSARY ix } & \text { ix }\end{array}$

EXECUTIVE SUMMARY Xi

$\begin{array}{lll}\text { I. } & \text { BACKGROUND } & 1\end{array}$

A. Research Context

B. Overview of Bangladesh Electricity Sector

C. Community Vulnerability to Extreme Weather Events 3

II. CENTRAL RESEARCH QUESTION AND SOLUTION COMPONENTS 4

A. Central Research Question 4

B. Solution Components

III. TOWARD A GESI-INTEGRATED ELECTRICITY DISTRIBUTION 7 PLANNING FRAMEWORK

A. Adapting the Smart Grid Architecture to Enhance Social Benefits 7

B. Electrification and Correlated GESI Indicators in Bangladesh 11

IV. A METHODOLOGY TO ASSESS RESILIENCE TO EXTREME WEATHER EVENTS 12

A. Assessment of Resilience $\quad 12$

B. Energy Loss Risk as a Measure of Resilience $\quad 14$

C. Aggregate Vulnerability Quantification $\quad 15$

V. TESTING THE ENERGY RESILIENCE FRAMEWORK 16

A. Designing a GESI-Integrated Reference Energy System 16

VI. A MODEL DISTRIBUTION SYSTEM WITH INCOME GENERATION 17

$\begin{array}{lll}\text { VII. } & \text { CONCLUSION AND RECOMMENDATIONS } & 18\end{array}$ 
$\begin{array}{ll}\text { APPENDIX 1: RESEARCH BACKGROUND } & 20\end{array}$

A. Bangladesh: Country Context 20

B. Extreme Weather Events in Bangladesh $\quad 20$

C. Gender and Intersecting Vulnerabilities and Community Resilience 22

D. Policies, Strategies, and Programs 23

APPENDIX 2: BANGLADESH: ENERGY POLICY AND GENDER CONSIDERATIONS 24

APPENDIX 3: INDICATIVE VULNERABILITY ASSESSMENT METHODOLOGY 25

A. Community Vulnerability Assessment $\quad 27$

B. Aggregated Vulnerability $\quad 29$

APPENDIX 4: ENERGY LOSS RISK EQUATION AND POWER 31

SYSTEM PLANNING RESILIENCE OPTIMIZATION 


\section{TABLES, FIGURES, AND BOXES}

\section{TABLES}

1 Operational Domains and Actors in Each Domain 8

2 Sociodemographic Metrics Correlating to Electrification 12

3 Community Resilience Criteria and Indicators 14

4 Aggregated Vulnerability Scoring Matrix (Indicative) 15

A3.1 Examples of Classes Associated with Rating Scales 25

A3.2 Example of Rapid Rating for Power System Vulnerability 26

A3.3 Example of Integration of Parameters with Different Weighting 26

A3.4Community Resilience Criteria and Indicators 28

\section{FIGURES}

1 Community Energy Resilience Issues Tree 6

2 From Research Questions to Solution Components 6

3 Operational Domains in the Electricity Industry 8

4 Overview of Customer Domains 9

5 Extended Architecture Layers to Include Sociodemographic Layer 10

6 Community Vulnerability Classes 29

7 Example of Aggregated Vulnerability Scoring Matrix 30

\section{BOXES}

1 Indigenous or Local Knowledge on Disaster Resilience $\quad 21$

2 Gender Equality and Social Inclusion in ADB-Assisted Disaster Risk Management Projects 22 


\section{ABBREVIATIONS}

BDRC Bangladesh Development Research Center

BPDB Bangladesh Power Development Board

GESI gender equality and social inclusion

ICT information and communication technology

IDCOL Infrastructure Development Company Limited

IEEE Institute of Electrical and Electronics Engineers (USA)

NIST National Institute of Standards and Technology (US)

SGAM smart grid architecture methodology

UNDP United Nations Development Programme 


\section{GLOSSARY}

Community Energy Resilience

Distributed Generation

Exposure

IEEE Smart Grid Architecture Methodology

Islanded Power System

Energy Loss Risk

Power Grid

Electricity Distribution System

Power System Redundancy

Reference Energy System

Renewables
A community's ability to respond or recover from the adverse impacts of electricity supply disruptions.

Power generation that occurs locally and/or is situated within a distribution network (rather than being fully provided by centralized power plants).

Amount of power not supplied to customers and that cannot be supplied from other sources of energy.

Refers to the Institute of Electrical and Electronics Engineers' (USA) working platform for smart grid design using a domain-based approach.

A section of a power grid with the ability to keep on running independently when connections to grid fails.

A measure in kilowatt-hour ( $\mathrm{kWh}$ ) of the energy at risk from extreme weather events across a defined territory.

A system of transmission and distribution lines operated by one or more control centers, synchronously connecting electricity producers and consumers.

A network of electrical components deployed to distribute electric power to end users.

Duplication of critical components or functions of a power system such as generators, transformers, or power lines to increase the reliability of the system, usually in the form of a backup or fail-safe against system failure, or to improve actual system performance.

A network representation of all of the technical activities required to supply various forms of energy to end-use activities; analytical techniques are described to examine all operations involving specific fuels including their extraction, refinement, conversion, transport, distribution, and utilization; each of these activities is represented by a link in the network for which efficiency, environmental impact, and cost coefficients may be specified; the network is quantified for a given year with the level of energy demands and the energy flows through the supply activities that are required to serve those demands.

Renewable energy sources (commonly referred to as renewables) include biomass and waste, geothermal, hydropower, solar energy, wind power, and ocean energy (tidal and wave energy). 
Smart Grid

Social Inclusion

Technology Innovation

Upazila

Vulnerability
An electrical network which includes a variety of operational and control measures including smart meters, smart appliances, renewable energy resources, and energy-efficient resources; it is also an adaptive system, embodied by the classic electrical grid but with a variety of modern concepts and technological resources appended, including but not limited to smart meters, smart appliances, renewable energy resources, distributed generators, information technology infrastructure and energy-efficient resources.

The process of improving the terms of participation in society, particularly for disadvantaged people, through enhancing opportunities, access to resources, voice, and respect for rights.

A new product and/or process or a significant improvement in a product and/or process, usually the result of research and development, with better than average commercialization or adoption potential.

The second-lowest tier of regional administration in Bangladesh.

The propensity or predisposition to be adversely affected. 


\section{EXECUTIVE SUMMARY}

ADB South Asia Working Paper Series No. 61, Energy Technology Innovation in South Asia-Implications for Gender Equality and Social Inclusion (2018) recommended testing an energy system that integrates gender equality and social inclusion (GESI) and community resilience performance measures. The proposed area of focus was a remote community where household electrification quality and supply need to be improved to support local economic development. Toward this aim, this paper proposes a framework for mainstreaming GESI performance in electricity distribution system planning and establishes a methodology for measuring and comparing community and electricity distribution system resilience to extreme weather events, and clarifies how the approach can be tested in Bangladesh.

The proposed approach helps integrate and mainstream GESI in electricity distribution planning by asking policy makers and decision makers to add a social and/or GESI layer atop the Institute of Electrical and Electronics Engineers (IEEE) Smart Grid Architecture Methodology. This added layer precedes the business and technical requirements that traditionally guide electricity network planning and design. To help measure whether GESI-integrated systems are meeting their social goals, this paper describes how social performance indicators can be used to quantify vulnerability and to assess whether a given intervention is helping to mitigate or lessen vulnerability. This paper concludes by outlining how a resilient energy system can be applied within a test project in a coastal community of Bangladesh served by a rural electricity cooperative society, to test and validate the proposed approaches and indicators for resilience, design and assessment. By building upon the rooftop solar photovoltaic infrastructure, the proposed test project would aim to enhance economic productivity by rewarding micropower producers among the target community, while also enhancing resilience in the face of adverse weather.

The main contribution of this design and methodology for a GESI-integrated resilient electricity distribution system is the equal consideration it affords to both the technical and social aspects of project design. It proposes to track sociodemographic indicators as fundamental measures of distribution system performance. The study further proposes a risk-based approach to planning electricity distribution systems-factoring for how a proposed system would enhance community resilience to extreme weather events. 



\section{BACKGROUND}

\section{A. Research Context}

1. ADBSouth Asia Working Paper Series No. 61, Energy Technology Innovation in SouthAsia-Implications for Gender Equality and Social Inclusion (2018), ${ }^{1}$ recommended testing an electricity supply system that integrates gender equality and social inclusion (GESI) and community resilience performance measures. The paper proposed testing the design in a remote community where household electrification quality and supply need to be improved to support local economic development. To further this aim, this paper proposes a framework for mainstreaming GESI performance in electricity distribution planning, and establishes a methodology for measuring and comparing community and electricity supply resilience to extreme weather events. The paper presents how the proposed project design framework may be tested in Bangladesh.

\section{B. Overview of Bangladesh Electricity Sector}

2. Ensuring "access to affordable, reliable, sustainable and modern energy for all," is one of the fundamental requirements for sustainable development of Bangladesh as well as globally, as highlighted in Sustainable Development Goal No. 7 of the United Nations 2030 Agenda. ${ }^{2}$ As of July 2021, about 99.5\% of the population had access to electricity, ${ }^{3}$ up from 50\% in $2011 .{ }^{4}$ In Bangladesh, although electricity generation and delivery capacity were increased significantly in recent years, the per capita electricity consumption of 378 kilowatt-hours ( $\mathrm{kWh}$ ) in fiscal year (FY) $2020^{5}$ was significantly below other countries in South Asia. ${ }^{6}$ Providing electricity to the remaining population and meeting the growing demand from existing and new customers in household, commercial, and industrial sectors continue to be government priorities, requiring investments in generation, transmission, distribution, and power quality improvement.

3. Load shedding to overcome generation capacity shortages were a regular practice before 2018. While large-scale load shedding is now a rare occurrence, the unreliability of power supply largely owing to weaknesses in the distribution network continues to be a major challenge, particularly for remote areas and isolated and vulnerable communities. Special projects have been launched and some have been already implemented (such as new grid substations in Rangamati and Khagrachari in Chittagong Hill Tracks to strengthen grid supply to feed the distribution network) to provide access to communities that still remain unserved by the grid. ${ }^{7}$ To optimize resources, Bangladesh's efforts to reach $100 \%$ electrification include a plan to leapfrog the extension of traditional electricity distribution infrastructure by mainstreaming smart metering, smart grid technologies, and other power system innovations from the outset.

4. According to the Bangladesh Power Development Board (BPDP) 2020 Annual Report, Bangladesh produced approximately $72 \%$ of its national electricity requirements from natural gas, with the

\footnotetext{
R. Mohideen. 2018. Energy Technology Innovation in South Asia-Implications for Gender Equality and Social Inclusion. Working Paper Series. No. 61. Manila: Asian Development Bank.

2 United Nations, Department of Economic and Social Affairs. 2015. Sustainable Development Goals. New York.

3 Government of Bangladesh, Ministry of Power, Energy and Mineral Resources, Power Division, Power Cell. 2021. Bangladesh Power Sector at a Glance. Dhaka.

4 Bangladesh Power Development Board. 2020. Annual Report, 2019-2020. Dhaka.

5 Fiscal year 2020 refers to the fiscal year starting 1 July 2019 and ending on 30 June 2020.

$6 \quad$ India reported 1,181 kWh per person in FY2019, Sri Lanka reported 670 kWh per person in 2019. U.S. Energy Information Administration. 2020. Electricity Consumption: International. Washington D.C.

7 The Bangladesh Rural Electrification Board has recently launched a project to lay 48 kilometers (cumulative) medium-voltage sub-marine cables and distribution lines over 33 river crossings, to achieve 100\% and uninterrupted electricity supply to off-grid areas, to reach villages isolated owing to rivers.
} 
remainder produced from furnace oil (13\%), coal (4\%), or imported from India (9\%). The contribution of renewable energy to grid electricity supply is small, at less than $2 \%$, and mostly from hydropower plants. A cumulative capacity of about 530 megawatt (MW) of solar photovoltaic systems is in operation by mid 2021, about $350 \mathrm{MW}$ of it off-grid, in the form of solar home systems and for water pumping for irrigation. Bangladesh's gas reserves are expected to deplete rapidly, resulting in the country resorting to liquefied natural gas imports. To diversify the energy mix, Bangladesh plans to continue to import both gas and coal. Several gas-fired and coal-fired power plants are under construction. Targets set in the 2008 Renewable Energy Policy of Bangladesh to achieve a renewable energy-based generation capacity share of $5 \%$ by 2015 and $10 \%$ by 2020 have not been reached yet.

5. Renewable energy accounts for about 3.4\% of the country's electricity production, of which electricity from solar power plants accounts for 53\%; hydroelectricity for $45 \%$; and the remainder comes from a mix of wind, biogas, and biomass. So far, solar home systems account for most of the electricity generation from solar energy. ${ }^{8}$ In its Intended National Determined Contributions to the Paris Agreement, Bangladesh has set an ambitious target of 1 gigawatt of generation from solar energy and 400 MW from wind energy by $2030 .^{9}$

6. Rooftop solar photovoltaic systems (off-grid). Bangladesh's solar home systems are the largest contributor to renewable energy-based electricity produced. This has positively impacted women beneficiaries through access to electricity, livelihood, and employment opportunities, including employment as technicians. Improved energy consumption levels through the inclusion of higher loads for economically productive activities have implications for the economic development of local communities. Now that the distribution network has expanded into areas previously not served, there is potential for small and micro power producers to emerge as an industry, using the available solar home systems as the catalyst. With the correct policy environment, strategies, and plans, women and marginalized groups may be encouraged to participate in electricity production as well.

7. Rooftop solar photovoltaic program (grid-connected). By 1 January 2021, the cumulative capacity of rooftop solar photovoltaic was $17.1 \mathrm{MW}$, across 1,166 installations in all distribution utilities in Bangladesh. One year ago, the installed capacity was $10.8 \mathrm{MW} .^{10}$ By mid-2021, SREDA estimates that there were about 1400 installations with a capacity of $25 \mathrm{MW}$. The net metering guidelines $2018^{11}$ lay out the technical and commercial guidelines to be followed by the distribution utilities and customers. Customers' surplus electricity generation from a net-metered rooftop solar photovoltaic system would be settled against the customer's consumption within a billing month. Any surplus is credited to the next billing month, in terms of energy ( $\mathrm{kWh}$ ). However, surplus electricity generation accumulated over the months and remaining unused by 30 June of each year, would be paid for at the bulk-supply rate applicable to 33 kilovolts level, as announced by Bangladesh Energy Regulatory Commission for that year.

8. Utility-scale solar photovoltaic projects. The Power Division plans to generate about $1500 \mathrm{MW}$ from solar PV over the next few years. Letters of intent and power purchase agreements have been issued for 21 renewable energy projects, adding up to $980 \mathrm{MW}$. The World Bank is assisting construction of the $50 \mathrm{MW}$ solar photovoltaic facility in Feni District by way of a concessionary loan. The project is being developed by the Electricity Generating Company of Bangladesh (EGCB), a subsidiary of the state utility Bangladesh Power Development Board (BPDB). The World Bank has pledged further support for capacity

8 S. Zobair. 2019. Greening the Energy Sector of Bangladesh. ADB Conference on Inclusive Energy Resilience in Bangladesh. Gazipur, Bangladesh, 23 April 2019.

9 Government of Bangladesh, Ministry of Environment and Forest. 2015. Intended Nationally Determined Contributions (INDC). Dhaka.

10 Government of Bangladesh, Sustainable and Renewable Energy Development Authority. 2021. Statistics of Installed Net Metering System. Dhaka.

11 Power Division, Ministry of Power, Energy and Mineral Resources, Bangladesh. 2018. Net Metering Guidelines 2018. Dhaka. 
building in renewable energy project preparation and to facilitate private sector investments in renewable energy. The World Bank support extends to Infrastructure Development Company Limited (IDCOL) to manage a concessionary financing scheme for both rooftop and ground-mounted solar photovoltaic facilities. ${ }^{12}$ The Asian Development Bank (ADB) has assisted the preparation of feasibility studies for two large solar photovoltaic power plants and two wind power plants..$^{13}$ Feasibility studies and business models for both wind and solar parks are being prepared under ADB assistance and are expected in 2021.

9. Projects supporting Bangladesh's efforts toward increased generation of electricity from renewable sources have demonstrated positive social outcomes, including for women's economic empowerment. Solar home systems have benefited women by enhancing livelihood and employment opportunities, including as technicians. ${ }^{14}$ These positive outcomes provide the rationale for the development of a methodology for an integrated approach to electricity distribution planning, taking into account social dimensions alongside technical and economic considerations.

10. Policy makers are faced with challenges as well as opportunities to foster equal social development and resilience through the development of electricity supply systems. As noted in ADB Working Paper No. 61, there is an opportunity to adopt a sociotechnical approach to electricity distribution planning to complement traditional technological and economic drivers.

\section{Community Vulnerability to Extreme Weather Events}

11. Bangladesh is prone to disasters from extreme weather events, including floods, riverbank erosion, tidal surges, etc. According to the Global Climate Index 2016, Bangladesh ranked sixth among countries most affected by extreme weather events between 1995 and $2014 .{ }^{15}$ It is the sixth-most flood-and erosionprone country in the world, with more than 88 million Bangladeshi living in low-lying flood-prone areas. ${ }^{16}$ These events are increasing in frequency and intensity due to climate change. Tropical cyclone Sidr on 15 November 2007 was the worst disaster triggered by natural hazard in Bangladesh in recent years and affected 29 palli bidyut samities (electricity distribution co operatives). ${ }^{17}$ Due to its geographical and economic susceptibility, the International Panel on Climate Change and other international organizations assessed that Bangladesh is likely to continue to suffer from the consequences of climate change earlier and more severely than most other countries. Significant efforts must therefore be deployed to strengthen national resilience, disaster preparedness, and capacity for response and recovery.

12. The poor and socially excluded are particularly vulnerable to climate variability and stress. Factors such as ethnicity, religion, caste status, and profession are common root causes for social marginalization, ${ }^{18}$ leading to the exclusion of poor women; households headed by women (including those headed by widows and divorced women); small ethnic groups; and other socially vulnerable groups such as religious minorities, the disabled, etc. In particular, these socially excluded groups are characterized by lower access to electricity deriving from social norms and traditions including hierarchical values, inadequate attention to the needs of women and other socially excluded groups, and lack of understanding of

12 World Bank. 2019. Bangladesh Receives \$185 Million World Bank Financing for Renewable Energy. News Release. 29 August.

13 ADB. 2020. Bangladesh: Power System Efficiency Improvement Project. Manila.

14 S. Khandker et al. 2014. Surge in Solar-Powered Homes - Experience in Off-Grid Rural Bangladesh. Washington, DC: The World Bank Group.

15 S. Kreft et al. 2015. Global Climate Risk Index 2016. Bonn: Germanwatch e.V.

16 UNDP Bangladesh. 2014. Resilient Bangladesh: UNDP Bangladesh Annual Report 2013-2014. Dhaka: UNDP Bangladesh.

17 It took approximately 7 months to restore the power system after Sidr. Source: Ghosh, Ashok Kumar. 2019. Community Energy Resilience: Framing the Issues and Identifying Social Metrics. ADB Conference on Inclusive Energy Resilience in Bangladesh. Gazipur, Bangladesh, 23 April 2019.

18 N. Kabeer. 2012. Women's Economic Empowerment and Inclusive Growth: Labor Markets and Enterprise Development. SIG Working Paper 2012/1. Ottawa: International Development Research Centre (IDRC). 
social inequalities. ${ }^{19}$ Small ethnic groups have very limited access to electricity due to the remoteness of most settlements, and lack of information on existing technologies and financial support available from different agencies for means to acquire them. The cost of electricity services and the inability of poor and marginalized groups to pay, are other factors affecting access to electricity.

13. Successive policies have outlined the government's commitment to disaster management, including support for vulnerable groups. The government designed the Bangladesh Climate Change Strategy and Action Plan 2009, defined a National Plan for Disaster Management for 2010-2015, and in 2012, set up a dedicated Department of Disaster Management under the Ministry of Disaster Management. Bangladesh has disaster management committees at different levels. The Disaster Management Act of 2012 affords preferential support in these efforts to ultra-poor and underprivileged communities such as tribal groups; small ethnic groups; and anthropological communities that are deprived of socioeconomic and other facilities, especially older persons, women, children, and people with disabilities. The government also leads the implementation of the Cyclone Preparedness Programs and the National Resilience Program.

\section{CENTRAL RESEARCH QUESTION AND SOLUTION COMPONENTS}

\section{A. Central Research Question}

14. To recap and elaborate on the country context provided in section I, significant contextual points can be summarized as follows:

(a) Bangladesh is a fast-growing economy, but unreliable power supply especially in the distribution network remains a significant constraint on growth.

(b) For the population of 164.6 million people, as of $2019,{ }^{20}$ Bangladesh had a total installed generating capacity of 23,777 MW, which comprised 19,433 MW of on-grid power plants, 1,160 MW of imports, 2,800 MW of captive power, ${ }^{21}$ and $384 \mathrm{MW}$ of off-grid, renewable resource-based capacity.

(c) The Power System Master Plan 2016 estimated the peak demand to reach 13,300 MW by $2020,19,900 \mathrm{MW}$ by 2025 , and $28,000 \mathrm{MW}$ by $2030 .{ }^{22}$ The forecast reflects a compound average demand growth of about 7.7\% during 2020-2030. The Power System Master Plan 2016 was revisited by the Ministry of Power, Energy, and Mineral Resources in 2018, and the forecasts were revised upward to reflect the situation at that time. For example, the peak demand forecast for 2025 has been increased from 19,900 MW to 23,167 MW. Peak demand forecast for the year 2030 has been increased from 27,400 MW to 31,730 MW. ${ }^{23}$

(d) Although progress has been made in reaching out to households and small businesses with the electricity distribution network, gender gaps persist in access to other resources, technical training, labor force participation and employment, domestic violence, and an

\footnotetext{
19 A. Sen. 2017. Collective Choice and Social Welfare-Expanded Edition. Cambridge: Harvard University Press.

20 Bangladesh Bureau of Statistics. 2019. Bangladesh Statistics 2019. Dhaka.

21 Power generating capacity, typically operated on diesel, available with customers.

22 Government of Bangladesh, Ministry of Power, Energy and Mineral Resources. 2016. Power System Master Plan 2016. Dhaka.

23 Government of Bangladesh, Ministry of Power, Energy and Mineral Resources. 2018. Revisiting Power System Master Plan (PSMP) 2016. Dhaka (forecast demand with EE\&C, table 6, page 17).
} 
uneven burden of unpaid work, creating gender-differentiated impacts of climate-related disasters.

15. Based on Bangladesh's unique country context, key challenges can be summarized as follows:

a Bangladesh is vulnerable to major weather events, exacerbated by climate change (including extreme temperature, erratic rainfall, floods, droughts, tropical cyclones, rising sea level, tidal surges, salinity intrusion, and ocean acidification).

b Population density is high, and the population is mainly rural and widely dispersed all over the country.

c Lack of access to electricity or unreliability of available supply has gender-differentiated impacts, which range from a higher burden of unpaid labor to reduced economic opportunities and detrimental impacts on health.

16. Critically examining both the context and challenges, a key question emerges:

"How to design sustainable electricity distribution systems in Bangladesh that are resilient to major weather events, affordable and accessible by the greatest majority of local communities, including the most vulnerable, that enables social and economic empowerment and equitable access to livelihood and resources?"

17. To address this question, a helpful exercise is to deconstruct it as an "issues tree" (Figure 1). This approach renders complex problems more manageable by allowing researchers to identify lower-level challenges and solutions for electricity distribution planning and design. Deconstructing the research question in this way yields three main research objectives (Figure 2):

a designing a sociotechnical electricity distribution planning framework into which GESI can be integrated;

b defining a methodology for assessment of resilience of the electricity distribution system and the community; and

c identifying a test case for validating the framework and the methodology.

\section{B. Solution Components}

\section{An electricity distribution planning framework that is GESI-integrated.}

18. This component of the research aims to design a distribution planning framework that explicitly involves gender equality and social inclusion. This framework may be used by national policy makers and electricity distribution system planners to establish development objectives and distribution planning criteria.

19. This research seeks to identify critical socio demographic indicators, disaggregated by sex, that correlate to the availability of modern energy services (primarily electricity) to local communities. Examples of such indicators include income, employment, health, education, and access to information and communication technology (ICT). This research component also endeavors to define the conceptual linkages between the selected indicators and the power distribution planning framework, including how access to electricity for communities can act as a catalyst for improvement of the Human Development Index over time. 


\section{Figure 1: Community Energy Resilience Issues Tree}

Key Question

How to design a sustainable electricity distribution system in Bangladesh that are resilient to major weather events, affordable and accessible by the greatest majority of local

communities, including the most vulnerable, that enable social and economic empowerment and equitable access to livelihoods and resources?

\begin{tabular}{|c|c|}
\hline $\begin{array}{l}\text { How to ensure } \\
\text { sustainability in the long } \\
\text { term }\end{array}$ & $\begin{array}{l}\text { Plan for the balanced use of available } \\
\text { technologies, cost, and long-term } \\
\text { sustainability of electricity distribution } \\
\text { systems and resources. }\end{array}$ \\
\hline $\begin{array}{l}\text { How to encourage } \\
\text { social and economic } \\
\text { empowerment through } \\
\text { electricity access }\end{array}$ & $\begin{array}{l}\text { Identify target social benefits and adapt } \\
\text { the traditional techno-economic electricity } \\
\text { distribution planning and design } \\
\text { frameworks to include those benefits as } \\
\text { explicit objectives. }\end{array}$ \\
\hline \multirow{2}{*}{$\begin{array}{l}\text { How to ensure } \\
\text { affordability and } \\
\text { accessibility to } \\
\text { electricity for } ~ 100 \% \text { of } \\
\text { the population, } \\
\text { including the most } \\
\text { vulnerable } \\
\text { (inclusiveness) }\end{array}$} & $\begin{array}{l}\text { Identify and plan for the use of alternative } \\
\text { technologies to provide poor and } \\
\text { vulnerable communities with electricity } \\
\text { "beyond the last mile and the light bulb." }\end{array}$ \\
\hline & $\begin{array}{l}\text { Identify criteria and priorities to include in } \\
\text { the electricity distribution system planning }\end{array}$ \\
\hline \multirow{2}{*}{$\begin{array}{l}\text { How to improve the } \\
\text { resilience vis-a-vis } \\
\text { extreme weather } \\
\text { events for both } \\
\text { electricity systems and } \\
\text { communities }\end{array}$} & $\begin{array}{l}\text { resillence to extreme weather events by } \\
\text { design. }\end{array}$ \\
\hline & $\begin{array}{l}\text { Consider and increase the intrinsic } \\
\text { resilience of communities and } \\
\text { local/women/indigenous knowledge in the } \\
\text { installation, operation, and restoration of the } \\
\text { distribution systems. }\end{array}$ \\
\hline
\end{tabular}

Source: Authors.

Figure 2: From Research Questions to Solution Components

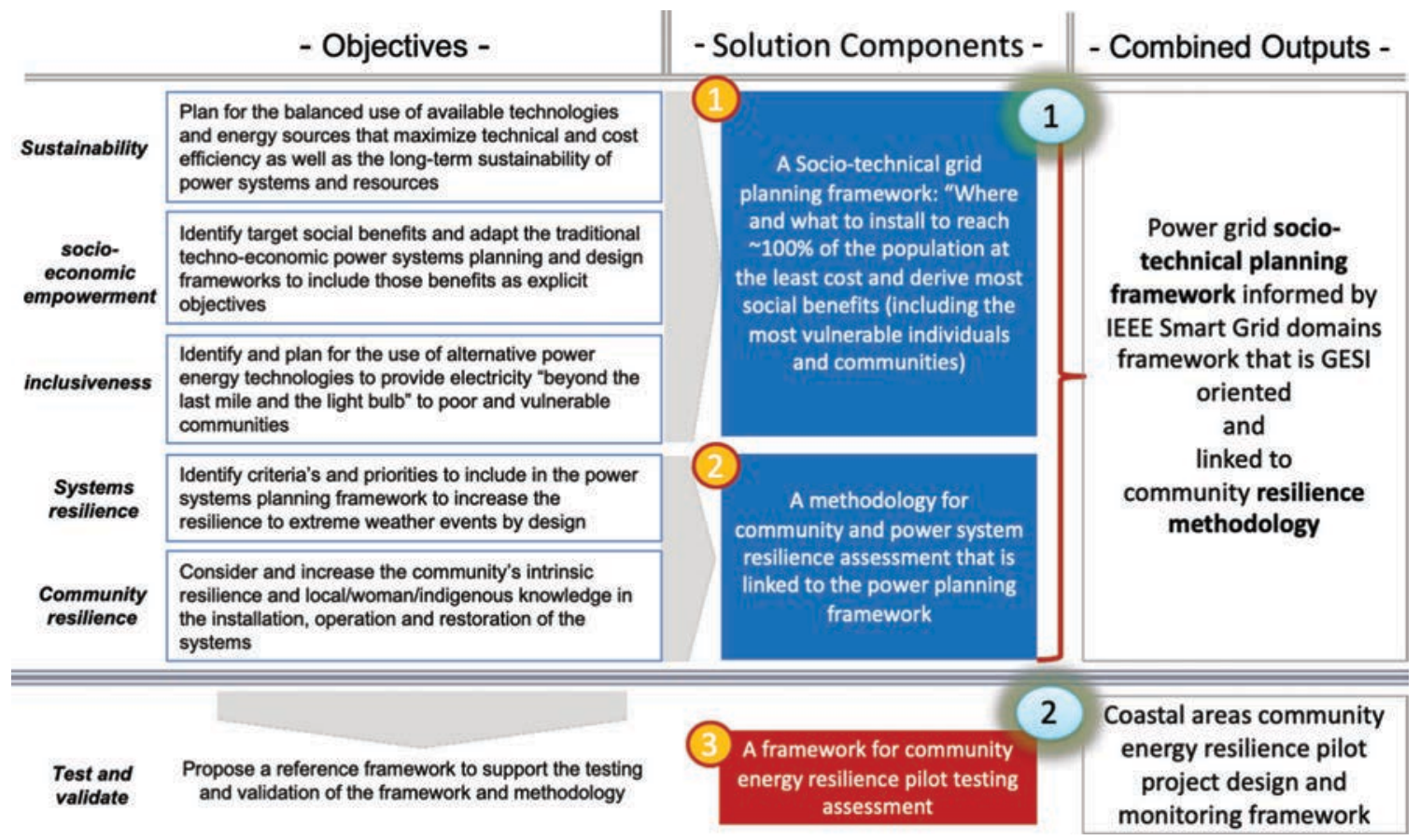




\section{A methodology to assess the resilience of electricity distribution systems to extreme weather events.}

20. This component aims to establish a methodology to assess and combine electricity distribution system resilience and local community energy resilience in the context of extreme weather events. The methodology defined and aggregated multiple resilience indicators and scoring systems, and established resilience linkages. A key aspect of this methodology is its focus on gender as a dimension of community resilience, and as such, it incorporates indicators such as women's time poverty and income.

\section{An approach for testing the methodology and design framework to enhance GESI mainstreaming and energy resilience in communities.}

21. This component aims to identify an entry point for implementing the proposed GESI-integrated resilient community electricity supply system in selected communities and monitoring its performance over time. The intended objectives of the test will be to validate the socio demographic framework defined in section III as well as the community resilience methodology defined in section IV.

\section{TOWARD A GESI-INTEGRATED ELECTRICITY DISTRIBUTION PLANNING FRAMEWORK}

22. Disaster management requires adaptative and iterative planning. This section proposes to adopt a prevailing sociotechnical approach to electricity distribution system design by adding GESI integration as an explicit system objective.

\section{A. Adapting the Smart Grid Architecture to Enhance Social Benefits}

23. Bangladesh has the opportunity to leapfrog traditional "last-mile" technologies in its effort to reach $100 \%$ electrification by adopting "smart grid" infrastructure. The "Smart Grid Vision" of the Institute of Electrical and Electronics Engineers (IEEE) and the National Institute of Standards and Technology (NIST) considers that the modernization or extension of power systems is essential to (i) increase reliability, resilience, sustainability, and energy efficiency; (ii) transition to renewable sources of energy; (iii) reduce greenhouse gas emissions; (iv) implement secure Smart Grid technologies to enhance privacy; (v) support a growing fleet of electric vehicles; and (vi) build a sustainable economy (NIST 2014). The goals of the IEEE and NIST smart grid architecture include: (i) Options - a broad range of technology options-both legacy and new, and be flexible enough to incorporate evolving technologies as well as to work with legacy applications and devices in a standard way; (ii) Interoperability - standard interfaces with other systems and manual processes (where standards exist); (iii) Maintainability - the ability of systems to be safely, securely, and reliably maintained throughout its life cycle; (iv) Upgradeability - the ability of systems to be enhanced without difficulty and to remain operational during periods of partial system upgrades; (v) Innovation - enable and foster innovation; (vi) Scalability - include architectural elements that are appropriate for the applications that reside within them; (vii) Legacy - legacy system integration and migration; (viii) Security - the capability to resist un-vetted/unauthorized intrusion, access, or use of physical and cyber assets; (ix) Flexibility - allow an implementer to choose the type and order of implementation; ( $x$ ) Governance - promote a well-managed system or systems that will be enabled through consistent policies over its continuing design and operation for its entire life cycle; and (xi) Affordability - enable capital savings as well as life cycle savings through standards-based operations and maintenance. 
24. IEEE and NIST have designed a conceptual model to support the design of smart grid infrastructure. The model helps to identify the main operational areas (domains and subdomains) involved in regulating, planning, implementing, and consuming electricity services provided by a smart grid (Figure 3). Underlying the conceptual model is a legal and regulatory framework that enables the implementation and management of consistent policies that apply to various actors and applications and their interactions.

25. The IEEE/NIST smart grid domains can be further segmented into actors (Table 1) and sub-domain areas (Figure 4) that encompass particular roles, institutions, services, etc. For example, the customer domain can be segmented into subdomains such as home, commercial/buildings, and industrial.

\section{Figure 3: Operational Domains in the Electricity Industry}

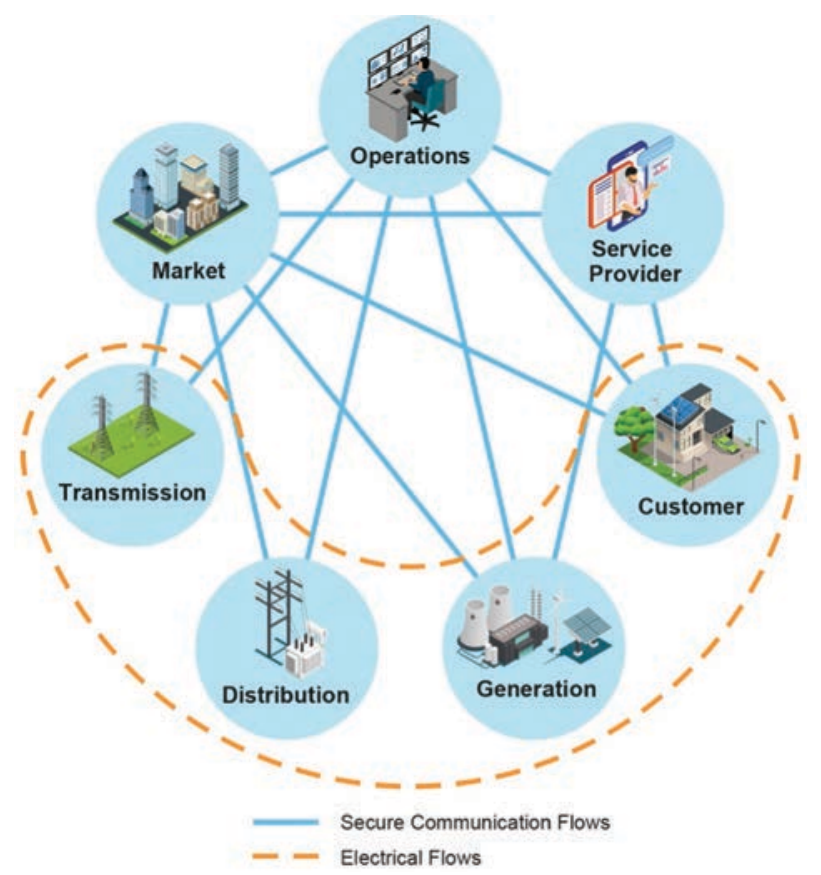

Source: Updated National Institute of Standards and Technology Smart Grid Framework 3.

Table 1: Operational Domains and Actors in Each Domain

\begin{tabular}{ll}
\hline Operational Domain & \multicolumn{1}{c}{ Actors in the Domain } \\
\hline Customers & $\begin{array}{l}\text { End users of electricity. Customers may also generate, store, and manage the use of electricity. } \\
\text { Traditionally, three customer types are defined: households, commercial, and industrial. }\end{array}$ \\
\hline Markets & Operators and participants in electricity markets. \\
\hline Service Providers & Organizations providing services to electricity customers and utilities. \\
\hline Operations & Managers of the electricity transmission and distribution networks. \\
\hline Distribution & Distributors of electricity to and from customers. May also store electricity. \\
\hline Transmission & Carriers of bulk electricity over longer distances. May also store electricity. \\
\hline Generation & Generators of electricity in bulk quantities. May also store electricity for later transmission.
\end{tabular}

Note: Legal or technical provisions for above may not be presently available in Bangladesh.

Source: National Institute of Standards and Technology Smart Grid Framework R3. 
Figure 4: Overview of Customer Domains

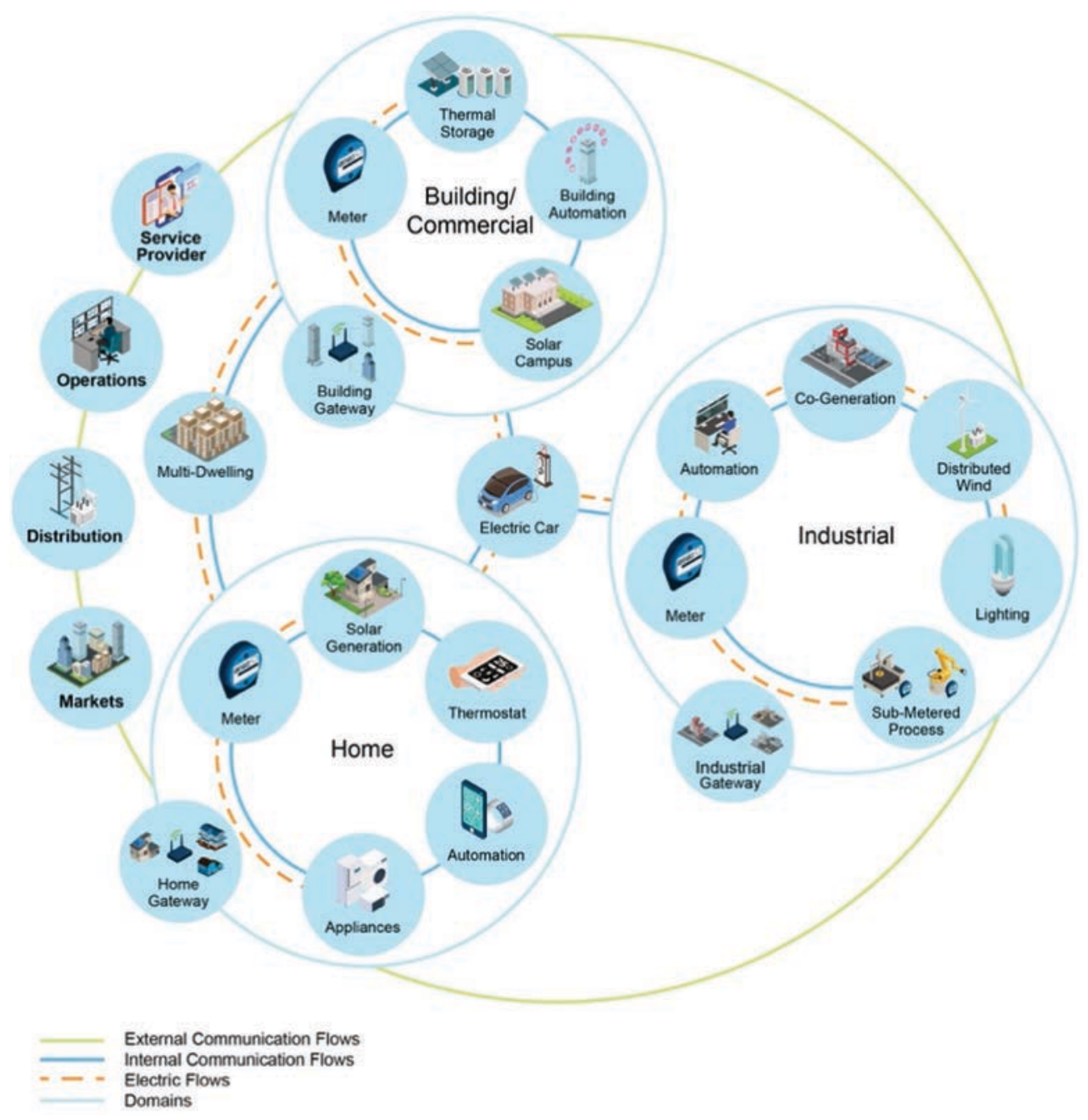

Source: Updated National Institute of Standards and Technology Smart Grid Framework 3.

26. In market economies, traditional approaches to electricity distribution planning seek to offset the costs and maximize economic benefits for each domain and sub-domain constituent. To help in these determinations, NIST developed the Smart Grid Architecture Methodology (SGAM) - a tool for structuring electricity distribution planning.

27. The SGAM identifies different "architecture layers" of a smart grid investment:

i. Business: describes the product and/or service strategy, and the organizational, functional, process, information, and geographic aspects of the business environment; it also identifies what personnel performs a task.

ii. Information: the structure, organization, flow of information, and protocols. It is a super set of the ICT concept of data architecture.

iii. Automation: types of automation (applications, sensors, etc.) required to support the information management requirements of the enterprise. 
iv. Technical: types of ICT needed to support automation requirements; includes computer and communications topologies and configurations.

28. Additionally, SGAM identifies four "iteration levels" across which each architectural layer can be elaborated:

v. Conceptual:models the actual business as it is conceptually understood by the stakeholders (domain actors, policy makers, and regulators).

vi. Logical: models the "systems" of the business or representations of the business that define its implementation.

vii. Physical: specifications for the infrastructure, hardware, and personnel needed to accomplish the task.

viii. Implementation: discrete systems (software, procedures, etc.) necessary to perform selected works.

29. The SGAM combines these architectural layers and integration levels as a matrix for clarifying the intersection of business-to-technical design choices and abstract-to-discrete planning and decision-making considerations, to help map the proposed architecture back to stakeholders and business requirements. The SGAM does not explicitly account for nonbusiness, social requirements. In Bangladesh and especially in rural areas, social needs are not always described in market terms. An extended architecture model inclusive of a GESI layer above the business layer is illustrated in Figure 5.

\section{Figure 5: Extended Architecture Layers to Include Sociodemographic Layer}

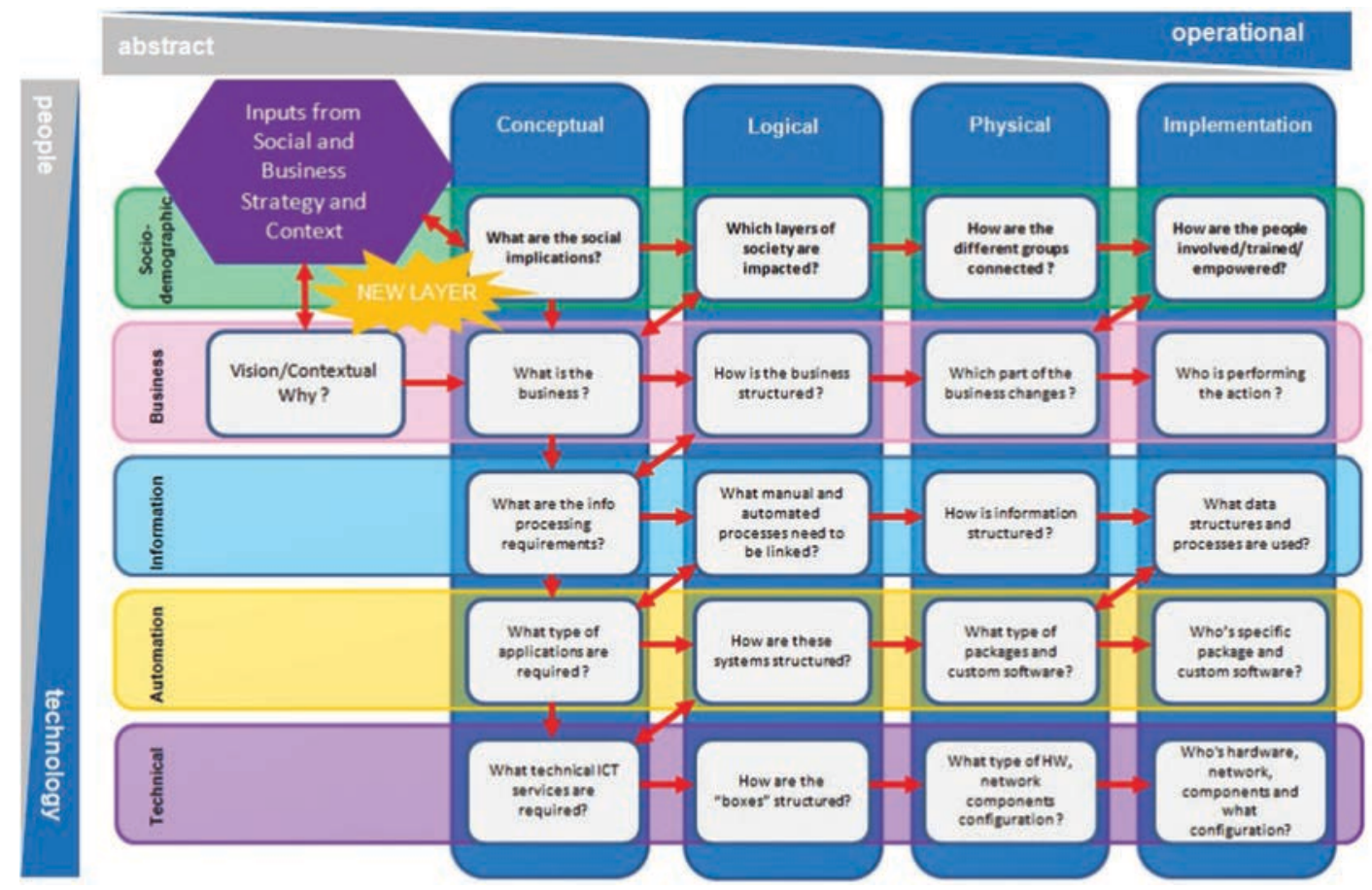

Source: National Institute of Standards and Technology Smart Grid Framework R3. 
30. Adding a social or GESI layer requires decision makers and utility planners to evaluate their corporate strategy and model, to define the desired social outcomes as the foundation of electricity distribution planning. This new layer ensures that electricity distribution planning:

i. includes sociodemographic performance indicators as requirements of distribution planning and design;

ii. integrates these requirements in the design and implementation of all other architecture layers; and

iii. monitors the satisfaction of these social/GESI requirements.

\section{B. Electrification and Correlated GESI Indicators in Bangladesh}

31. Correlations between access to electricity and social development have been demonstrated in terms of improvements to community farming and nonfarming incomes; ${ }^{24}$ increased study times of boys and girls; increased years of schooling. ${ }^{25}$ Under the UN 2017 review of the Sustainable Development Goals (SDGs), the Government of Bangladesh noted that increased access to electricity (from 48\% in fiscal year [FY] 2010 to 80\% in FY2016 with the objective of 100\% by FY2021) helped rural, and small and medium-sized enterprises to grow and generate employment. ${ }^{26}$

32. Yet analysis of the gender and social inclusion dimensions of electrification are relatively less explored. For example, Bangladesh reports on indicators for education, health, and economic and political empowerment under SDG5, which aims to "Achieve gender equality and empower women and girls." However, indicators for electrification are not included. Similarly, in planning "access to electricity for all" in a community, the different gendered impacts on women and men tend not to be well integrated with socioeconomic analyses. This gap likely stems from traditional approaches to electricity distribution planning, which are driven by technoeconomic rather than socio demographic factors. The study proposes to explicitly include GESI indicators as objectives or guiding principles for electricity distribution planning.

33. Socioeconomic demographic indicators identified by researchers as corollaries between access to electricity and increased well-being and empowerment of women and men, are presented in Table 2. While a custom group of indicators would be chosen to match the specific characteristics of a particular electricity distribution project, it could also be beneficial for aggregate analyses to identify a common pool of known correlative GESI indicators for distribution system resilience.

24 M. Masuduzzaman. 2013. Electricity Consumption and Economic Growth in Bangladesh: Co-integration and Causality Analysis. Research Study Series No. - FDRS 02/2013. Dhaka: Ministry of Finance, Government of Bangladesh.

25 S.R. Khandker et al. 2009. Welfare Impacts of Rural Electrification-A Case Study from Bangladesh. World Bank Policy Research Working Paper 4859. Washington, DC: World Bank.

26 Government of Bangladesh. 2017. Data Gap Analysis for Sustainable Development Goals (SDGs) Bangladesh Perspective. Dhaka: General Economics Division, Bangladesh Planning Commission; Government of Bangladesh. 2017. Eradicating Poverty and Promoting Prosperity in a Changing World. UN Sustainable Development Goals Program Bangladesh Voluntary National Review (VNR). Dhaka. 
Table 2: Sociodemographic Metrics Correlating to Electrification

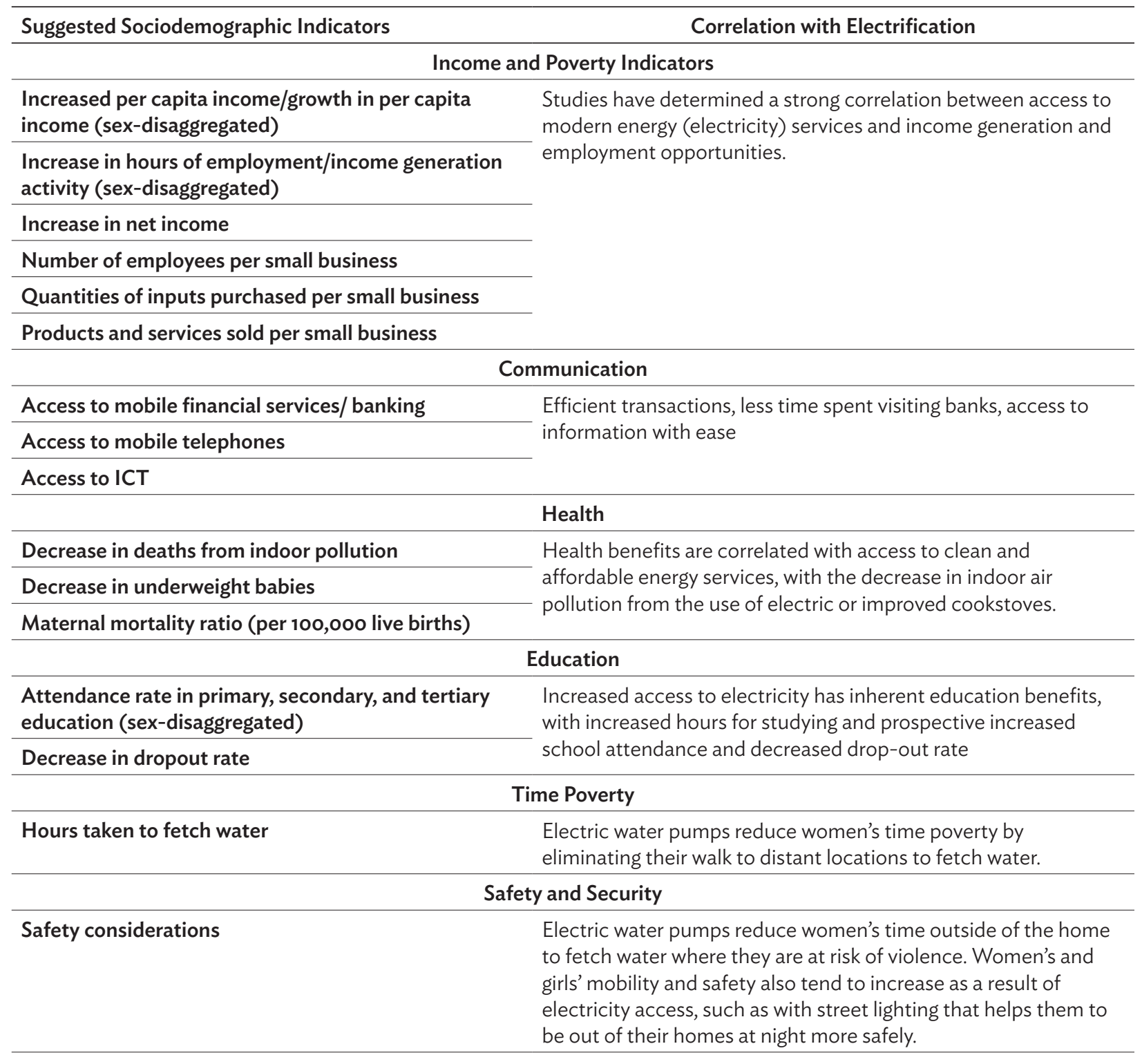

$\mathrm{ICT}$ = information and communication technology.fv

Source: ENERGIA, World Bank/ESMAP, and UN Women 2018.

\section{A METHODOLOGY TO ASSESS RESILIENCE TO EXTREME WEATHER EVENTS}

\section{A. Assessment of Resilience}

34. This section outlines a methodology to assess electricity distribution system resilience as well as the vulnerability of communities to the loss of energy access in case of extreme weather events. This methodology is intended to guide decision makers in identifying the geographic areas most at risk due to the technical vulnerability of the electricity distribution system and the vulnerability in access to electricity supply, for livelihood. This information may be useful in policy making, investment decisions, and distribution network planning and budgeting to increase resilience to disasters. The methodology to quantify the aggregated vulnerability is elaborated further in Appendix C. 
35. This methodology considers two aspects of resilience to extreme weather events. The first is the technical resilience of the power system in itself, where the power system studied can be the national power system as a whole (comprising the national grid, minigrids, and islanded systems, if any, as well as decentralized off-grid and individual electrification systems), or a technical or geographical subsection of the electricity distribution network. The second aspect considered is the community's energy resilience, understood as the ability of the community to resort to alternative sources of energy to sustain livelihood in case of a disruption in their main source of electricity as a consequence of a disaster. In that regard, the discussion will also address ways in which the community's overall resilience to disasters (continued access to communication, transport, water, food) is increased thanks to access to a reliable and resilient electricity supply. As part of the assessment of the community's energy resilience, a GESI analysis is recommended, to identify the resilience capacity of the most vulnerable when facing an extreme weather event.

\section{Power System Resilience}

36. The resilience and vulnerability of power systems can be measured according to the following factors. ${ }^{27} \mathrm{~A}$ methodology for quantifying these factors is further described in Appendix C.

i. The robustness of the system as well as its flexibility-design choices that enable the system to better resist extreme weather events. This includes the choice of location and routes, materials, technology, etc.

ii. The level of structural redundancy allows for continuity of supply despite physical damage to some infrastructure components. For instance, redundant transmission routes or the presence of distributed back up generation to increase the likelihood of preserved availability of continuous supply in the event of disaster damage.

iii. The smartness of the system-its intrinsic adaptability, controllability, and in-built capacity for recovery. A power system that can detect grid failure and automatically switch to 'islanded' mode, for instance, is intrinsically less vulnerable than one that requires constant grid connectivity or manual switching.

iv. The ability for fast recovery-ease of system repair and preparedness for a response to decrease system downtime. This further implies the quality of system maintenance, availability of crucial spare parts, and the capacity of teams to access damaged/failing equipment, including in remote locations. For instance, underground powerlines are less prone to damage, but when affected, they require more time to repair.

37. All measures to increase power system resilience comes at a cost and should be closely and thoroughly weighed in a well-informed "cost-benefit" analysis. While economic benefits are often considered, this study wishes to highlight that less measurable benefits are equally if not more important, namely social benefits for the most vulnerable groups that are less resilient.

\section{Community Resilience}

38. The vulnerability of communities in accessing electricity supply in the event of a disaster depends on multiple variables, such as:

a socioeconomic resourcefulness of households and communities;

b availability of early warning systems and shelters with stand-alone power generation capacities;

27 M. Panteli and P. Mancarella. 2015. The Grid: Stronger, Bigger, Smarter? Presenting a Conceptual Framework of Power System Resilience. IEEE Power and Energy Magazine. Vol. 13(3). pp. 58-66. 
c access to information and communication e.g., radio, TV, mobile phones, internet;)

d availability of local skilled labor to repair and restore the power system;

e availability of alternative sources of energy that can meet the basic living, farming, business, and other livelihood requirements, while the primary power supply is being restored;

$f \quad$ access to markets preserved in the aftermath of a disaster; and

g access to livelihood support services provided by government, private sector, and/or nongovernment organizations (NGOs).

39. In assessing community resilience, it is important to undertake GESI analysis-identifying potential exacerbating factors for vulnerable socioeconomic groups such as single women and households headed by women below the poverty line, widows, small ethnic groups, etc. Examples of indicators are presented in Table 3. Target indicators and the necessary granularity of analysis are context-specific and can be assessed using field surveys, analysis of historical data and previous disaster events, and community consultations.

Table 3: Community Resilience Criteria and Indicators

\begin{tabular}{|c|c|}
\hline Main Criteria & Indicators and Metrics \\
\hline Economic (E) & $\begin{array}{l}\text { - } \text { Cash income (Ca) } \\
\text { - Land ownership and/or use (L) } \\
\text { - Productive asset ownership and/or access and use (Pa) }\end{array}$ \\
\hline Knowledge (K) & $\begin{array}{l}\text { - Education } \\
\text { - Technical and/or skills training }\end{array}$ \\
\hline Information and Communication (I) & $\begin{array}{l}\text { Ownership or access to: } \\
\text { - Television } \\
\text { - Radio } \\
\text { - Internet } \\
\text { - Computers }\end{array}$ \\
\hline Technology and Infrastructure (T) & $\begin{array}{l}\text { Availability and access to: } \\
\text { - } \quad \text { Early warning systems } \\
\text { - Power generation assets } \\
\text { - } \quad \text { Shelters }\end{array}$ \\
\hline Governance (G) & $\begin{array}{ll}\text { - } & \text { Capacity } \\
\text { - Information management } \\
\text { - Service delivery } \\
\text { - GESI awareness }\end{array}$ \\
\hline Women's time poverty (W) & $\begin{array}{l}\text { - Access to pumped water } \\
\text { - Power for food processing equipment and medium power appliances. }\end{array}$ \\
\hline
\end{tabular}

Source: Authors.

GESI = gender equality and social inclusion.

\section{B. Energy Loss Risk as a Measure of Resilience}

40. To capture useful measures of vulnerability, it is important to continuously assess the communities and the power systems, and to calibrate parameters used for identifying vulnerabilities, particularly after an extreme weather event. 
41. Energy Loss Risk reflects:

- probability of disaster occurrence;

- probability that a disaster event would negatively affect the power distribution system;

- propensity of the physical power distribution system to be affected: if negatively affected, the extent of ramifications; 28

- amount of energy loss from physical disruption-in otherwords, the overall electricity generated, transmitted, and distributed by the infrastructure-which would be at risk of no longer being supplied were the system to fail. At the scale of a community, this can be characterized as the community's mean energy consumption availed from the power system studied;

- duration of disruption and/or downtime; and

- community vulnerability/resilience: its intrinsic ability to repair/isolate/restart the system or to resort to alternative sources of energy.

42. Assigning values for Energy Loss Risk aims to facilitate comparisons. At the national level, this methodology can be used for assessing the effectiveness of electricity distribution planning as well as for informing consideration of specific modifications or alternative schemes and helping to configure lowrisk energy portfolios - in other words, the highest resilience. The equation to calculate the energy loss is described in Appendix D.

\section{Aggregate Vulnerability Quantification}

43. Both power system vulnerability and community vulnerability can be aggregated through a double-entry table, shown in Table 4.

Table 4: Aggregated Vulnerability Scoring Matrix (Indicative)

\begin{tabular}{|c|c|c|c|c|c|c|}
\hline & & \multicolumn{5}{|c|}{ Community Vulnerability } \\
\hline \multirow{8}{*}{ 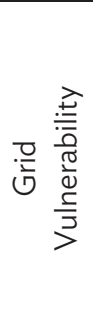 } & & Class 1 & Class 2 & Class 3 & Class 4 & Class 5 \\
\hline & Class 1 & 0.01 & 0.05 & 0.2 & 0.5 & 0.75 \\
\hline & Class 2 & 0.05 & 0.1 & 0.3 & 0.6 & 0.8 \\
\hline & Class 3 & 0.2 & 0.3 & 0.6 & 0.75 & 0.9 \\
\hline & Class 4 & 0.5 & 0.6 & 0.75 & 0.9 & 0.95 \\
\hline & Class 5 & 0.75 & 0.8 & 0.9 & 0.95 & 1 \\
\hline & Class 6 & 0.75 & 0.8 & 0.9 & 0.95 & 1 \\
\hline & Class 7 & 0.8 & 0.9 & 0.9 & 0.95 & 1 \\
\hline
\end{tabular}

Source: Authors.

44. Aggregated calculation of vulnerability in this example, ranges from 0 to 1 , with 0 corresponding to low vulnerability hence high resilience, and one corresponding to high vulnerability and low resilience. The aggregated vulnerability can be subdivided into discrete classes of low, medium, and high vulnerability (green, orange, and red in Table 4). The aggregated value of vulnerability is used as a factor in the Energy Loss Risk calculation that multiplies that factor with the probability of disaster occurrence for that community and the amount of energy loss from disruption (Appendix D). Areas ranked as "High Energy Loss Risk" stand out as areas for priority action to decrease the impact that disaster may cause on communities and their power supply in these areas.

28 The probability of the system to be affected and, if affected, the extent to which the system would be disrupted, can be combined into one parameter: the technical vulnerability of the power system. 
45. The methodology can be applied iteratively for network extension and reinforcement at all levels of granularity or a different geographic scale (at division or community levels). With adequate data, comparisons across regions could help to prioritize certain types of investment to increase disaster resilience. Electricity distribution planning and design can help to minimize the risk under budget and social benefit constraints.

\section{TESTING THE ENERGY RESILIENCE FRAMEWORK}

46. The previous sections presented (i) an electricity distribution network planning and design framework that is GESI-integrated and (ii) a methodology to assess resilience to extreme weather events. This section elaborates an actionable context for testing and validating the design framework and methodology presented in the above sections. System design may be tested in a rural or a semiurban setting with a weak distribution network, to improve the quality of the electricity supply. Given the higher incidence of disasters along coastal areas in Bangladesh, an appropriate test setting is a coastal upazilaand specifically within a community characterized by high proportions of vulnerable peoples. Heightened resilience would be realized by upgrading the existing distribution system to a resilient power system (including extensions to enable 100\% coverage of households and businesses). Validation would occur by tracking whether the enhanced system design and delivery improve the community's perception and experience of disaster vulnerability.

47. The purpose and scope of testing would be to assess and quantify the positive social benefits derived from access to electricity and to define indicators for measuring community resilience to extreme weather events.

\section{A. Designing a GESI-Integrated Reference Energy System}

48. The GESI-integrated reference energy system mode ${ }^{29}$ incorporates community energy resilience and is based on the following features:

i. GESI-integrated community vulnerability assessment and classification.

ii. GESI-responsive system constraints are based on prioritizing the reduction of women's time poverty and improving women's economic empowerment. ${ }^{30}$

iii. Indicator data, integrating technology data in analyzing the gender division of labor in productive and reproductive activities.

49. The strength of the reference system is that it provides the community with relevant information and assesses what the community wants and needs through a participatory consultation process. Upon examination of the entire system, it can be assessed that the GESI integrated sociodemographic criteria

29 R. Mohideen. 2018. Energy Technology Innovation in South Asia Implications for Gender Equality and Social Inclusion. Manila: ADB.

30 This is achieved through increased income linked to the World Bank global tracking framework for electricity consumption Tiers 3-5, to provide an optimal level of electricity consumption for pumped water and medium power appliances for food processing, that is going beyond simply enabling lighting (going beyond the light bulb). 
or constraints in the system, correlated with access to modern energy services, now include: (i) women's income, (ii) education and skills of women and girls, and (iii) women's time poverty. These criteria can be incorporated as indicators, with set activities and targets, in the project design for a given upazila. ${ }^{31}$

50. The test project shall build on current analysis of gender considerations in applicable energy policy (Appendix B) and define specific sociodemographic indicators. Definition of a community energy resilient system could be done through a combination of individual solar photovoltaic systems.

51. Proposed key activities and milestones of this test project are set out below. This general framework would be further elaborated through field visits to specific communities in coastal areas. Monitoring would occur via household surveys and participatory consultation processes as well as with the cooperation of government agencies. The government requires to provide counterpart support in the form of counterpart staff, office space for the project management unit, meeting venues, access to data and information of the international and national consultants, staff time to review outputs of consultants and conduct periodic field visits, and other in-kind contributions.

52. Lessons from the test project may be informative for establishing a national monitoring framework to more uniformly measure and track the improvement of identified sociodemographic indicator values for all energy projects, with lessons feeding back into the development of national energy strategy and project prioritization.

\section{A MODEL DISTRIBUTION SYSTEM WITH INCOME GENERATION}

53. The foregoing methodology can be applied in the design and implementation of the most commonly used form of distributed generation: rooftop solar photovoltaic systems on the principle of net metering. Bangladesh has a system in which customers can connect a rooftop solar photovoltaic system to the grid. During the day, electricity produced is used in the household and the surplus flows to the grid. In the night, all the electricity requirements are purchased from the grid. The regulation requires that for each month, the customer electricity import is set off against any exports, but the customer continues to pay the fixed charge and the demand charges.

54. However, the uptake by household customers of this concession is limited, most likely because of (i) lower electricity prices, especially to subsidized customer categories, causing the cost of energy delivered from solar photovoltaic to be perceived to be higher than purchases from the grid, (ii) solar photovoltaic system costs still being above the capacity of most household customers to self-finance or be financed through a personal loan, and (iii) absence of active promotion of rooftop solar photovoltaic as a policy by the government or utilities by way of either concessionary financing or preferential rates. Since the net metering guidelines were issued in 2018 , by mid 2021, a cumulative $25 \mathrm{MW}$ of rooftop solar photovoltaic systems have been installed over three years, across about 1400 customer installations.

55. Since the grid is expanding with a pledge to connect all households, the requirement is to ensure that grid supply is reliable. Although detailed information on distribution network reliability in regions exposed to cyclones is not available, it is widely accepted that bad weather including cyclones causes long shutdowns. Bangladesh, pending grid expansion to reach all households, has previously embarked

31 The upazilas are the second-lowest tier of regional administration in Bangladesh. The administrative structure consists in fact in Divisions (8), Districts (64), Upazilas, and Union Parishads (UPs). 
on providing solar home systems, and as of January 2019, an estimated 4.13 million solar home systems were in operation, facilitated by IDCOL, as the only means of supplying electricity to such households. IDCOL's previous plans to install a further 2 million solar home systems by end of 2021 have now been downsized in the face of the government's accelerated drive to make grid electricity accessible to all.

56. Rooftop solar photovoltaic can continue to be an integral part of the government's strategy to provide electricity to all by 2021. As the distribution network expands to reach all households and other retail customers, it is most likely that some or all of the solar home systems may be disconnected. Unless the transition from a solar home system to a grid-connected solar photovoltaic system is carefully managed, a sizable majority of stand-alone solar home systems may fall into disuse over the next few years.

57. Solar home systems with storage provide the best security against grid outages. On the one hand, when the grid is active, rooftop solar photovoltaic systems can contribute renewable energy to support normal operations. That is, households produce and use electricity from the solar photovoltaic system, with the surplus flowing into the grid. This is favorable in that it maximizes the productive capacity of household photovoltaic systems and provides an opportunity for households to receive monthly incomes or credits for selling the surplus energy to the grid. When the distribution network is inoperative for any reason, the system can be engineered to draw from a battery backup that is charged by the solar photovoltaic. The system would supply a few hours of home electricity requirements during a grid failure, according to the capacity of the battery, its level of stored energy, the consumption in the household for appliances, and the intensity of livelihood activities. During prolonged outages (such as after a major cyclone), the solar photovoltaic would continue to charge the battery and provide a limited electricity supply.

58. There are several requirements to implement a resilient grid that can support income generation for households and at the same time, provide a resilient electricity supply. Assuming the distribution network is already available, major components include (i) providing rooftop solar photovoltaic systems to all deserving households (women-headed, small businesses) along with a battery and a hybrid inverter, ${ }^{32}$ (ii) adopting a policy to allow regular payment for surplus energy dispatched by the household to the grid, and (iii) establishing an adequate monthly fixed charge to ensure the network costs of the local electric cooperatives, or palli bidyut samities (commonly called PBS), are met, in order not to jeopardize the system of rural electricity cooperatives operating successfully at present. Financing arrangements for the rooftop solar photovoltaic system with battery and hybrid inverter, requires to be arranged through concessionary financing schemes, the details of which and the financing model needs to be worked out, along with the financial and economic viability of the scheme from customer, utility, and national perspectives.

\section{CONCLUSION AND RECOMMENDATIONS}

59. Decision makers have limited control over the probability of disaster occurrence (which can be addressed with longer-term policies such as those against climate change) or the degree of energy exposure. With increasing population growth, industrialization and development, energy consumption and demand are expected to increase and consequently the amount of energy carried by the system, and the risk of system failure is expected to increase rather than decrease. Vulnerability is the parameter

32 A hybrid inverter may serve as a grid-tie inverter, a battery charger or an off-grid inverter, depending on the availability of solar resource, grid and the stored energy in the battery. 
that decision makers can help to control when planning how to increase the resilience of the power system during and following disasters.

60. This research design framework and methodology are intended to help define, quantify, and monitor power systems, community resilience and vulnerability for a GESI-integrated community energy-resilient system. In this process:

i. GESI has been embedded in the methodology from start to finish, from the key question to the outputs and outcomes.

ii. Quantifiable sociodemographic metrics as objectives are introduced as an overarching layer in the IEEE Smart Grid Architecture Methodology that specifies the guiding operational considerations for each subsequent architecture layer.

iii. Key sociodemographic metrics that are GESI-integrated have been developed to identify which improvement due to access to electricity would empower women and vulnerable people and communities.

iv. The proposed framework would enable policy makers to incorporate explicit GESIintegrated empowerment objectives, including women's economic empowerment, in power grid design and planning. They would select which socio demographic metrics to monitor and set target objectives as requirements in the IEEE smart grid architecture model, while providing adequate resources for their implementation.

61. Integrating power systems and community energy resilience creates a more nuanced understanding of community resilience based on criteria and subcriteria. This, in turn, contributes to the improved design of community energy systems. This includes taking into consideration the process of system design to weigh and prioritize the criteria through participatory consultation activities in the community.

62. The research design framework component explicitly introduces sociodemographic metrics in both the sociotechnical planning framework and the resilience methodology. It is proposed to track the improvement of those metrics as an objective in the design and planning of the electricity distribution systems. The methodology component further proposes an integrated risk-based approach to measure community and distribution system resilience to extreme weather events. The novelty of the proposed methodology is derived from problem formulation that explicitly considers both the technical power system resilience and the social community energy resilience in quantifiable terms that are linked to distribution system planning via an optimization problem.

63. This methodology may be useful as a national monitoring framework that identifies social and GESI-integrated outcomes to be accomplished using previously identified sociodemographic indicators to measure and track the improvement of these indicators and then feedback this information into system design. 


\section{APPENDIX A: RESEARCH BACKGROUND}

\section{A. Bangladesh: Country Context}

1. Bangladesh has a population of 164.6 million (2018). Its gross domestic product (GDP) in FY2019 was $\$ 302$ billion or $\$ 1,829$ per capita. ${ }^{1}$ The country has progressed into a middle-income country status, with GDP growing at more than $6 \%$ per year. Bangladesh moved from a low human development category to medium category by 2016. The percentage of the population below the national poverty line decreased from 24.3\% of the population in 2016 to $21.8 \%$ in $2018 .{ }^{2}$ In 2018, its Human Development Index score went up to 0.614 from 0.515 in 2013 and its rank to 135 from $142 .{ }^{3}$ The poverty reduction has taken place in the context of rapid urbanization.

2. In the World Economic Forum's Global Gender Gap Report 2020, Bangladesh ranks 50th out of 153 countries in the global gender gap index. This means that Bangladesh is ahead of over 100 countries in closing the gender gap. In 2015, the maternal mortality ratio was 176 deaths per 100,000 live births. ${ }^{4}$ Although this was below the Millennium Development Goal target of 143, this represents a significant improvement from 472 in 1990-1991 and 318 in 2000. At 33\%, women's labor force participation in Bangladesh is lower than in Bhutan, Maldives, Nepal, and Sri Lanka, but higher than in India, and Pakistan. More than $90 \%$ of women in paid employment are in the informal sector. Agriculture accounts for $53.5 \%$ of the female workforce, compared with $41.7 \%$ of male workers. More than $50 \%$ of employed women are "contributing family helpers" and unpaid domestic, agricultural, and agroprocessing labor remains a major barrier to female workforce participation. Women are vastly underrepresented in decision-making jobs, accounting for only $20.6 \%$ in Parliament and $8 \%$ in ministerial positions - as this is high compared to most countries, Bangladesh ranks seventh (over 153 countries) in political empowerment. In technical and professional jobs, women are $24 \%$ of the workforce. ${ }^{5}$ In the power sector in Bangladesh, women account for $10 \%$ of the workforce and only $6 \%$ of technical jobs. A contributing factor is the gender gap in education in Bangladesh: women make up 12\% of engineering students and $15 \%$ of engineering faculty. ${ }^{6}$

\section{B. Extreme Weather Events in Bangladesh}

3 The economic growth of Bangladesh has been held back due to climate change impacts and disasters. Bangladesh is ranked sixth for extreme weather events in the last 20 years, ${ }^{7}$ fifth-most vulnerable among 170 countries, ${ }^{8}$ and sixth-most flood- and erosion-prone country in the world ${ }^{9}$-more than 88 million of the population live in low-lying flood-prone areas. It is considered a disaster-prone country

\footnotetext{
Bangladesh Bureau of Statistics. 2019. Bangladesh Statistics 2019. Dhaka.

ADB. 2017. Poverty Data: Bangladesh. Manila.

3 UNDP. 2019. Beyond Income, Beyond Averages, Beyond Today: Inequalities In Human Development In The 21st Century.

Human Development Report 2019. New York.

4 The upazilas are the second-lowest tier of regional administration in Bangladesh. The administrative structure consists in fact in Divisions (8), Districts (64), Upazilas, and Union Parishads (UPs).

5 This is achieved through increased income linked to the World Bank global tracking framework for electricity consumption Tiers 3-5, to provide an optimal level of electricity consumption for pumped water and medium power appliances for food processing, that is going beyond simply enabling lighting (going beyond the light bulb).

6 World Bank. South Asia Region. Pathways to Power: South Asia Region Baseline Assessment for Women Engineers in the Power Sector. Unpublished.

7 S. Kreft, S. and D. Eckstein, L. Dorsch, and L. Fischer. 2016. Global Climate Risk Index 2016 Who Suffers Most from Extreme Weather Events? Weather Related Loss Events in 2014 and 1995 to 2014. Briefing Paper. Bonn: German Watch.

$8 \quad$ S. Kreft, S. and D. Eckstein. 2013. Global Climate Risk Index 2014: "Who Suffers Most from Extreme Weather Events? Weather Related Loss Events in 2012 and 1993 to 2012.” Briefing Paper. Bonn: German Watch.

9 UNDP. 2014. Resilient Bangladesh: UNDP Bangladesh Annual Report 2013-2014. Dhaka: UNDP Bangladesh.
} 
due to flood, riverbank erosion, heavy rainfall, cyclone, storm, and tidal surge, all of which are occurring with greater frequency and intensity, most likely attributed to climate change. Tropical cyclone Sidr on 15 November 2007 was the worst disaster triggered by natural hazard in recent times that affected 29 palli bidyut samities (electricity cooperative societies). It took approximately 7 months to completely restore the power system after Sidr. ${ }^{10}$ There is a $20 \%$ chance of potentially damaging wind speeds to occur in Bangladesh in the next 10 years. Bangladesh is exposed to a relatively high risk of tropical cyclones. The International Panel on Climate Change and other international organizations assessed that Bangladesh is expected to suffer earlier than most other countries from the consequences of climate change because of its geographical and economic susceptibility.

4. The poor and socially excluded are particularly vulnerable to climate variability and stresses. ${ }^{11}$ Rising average temperatures can affect living standards through negative impacts on, among others, agricultural and labor productivity, health, and migration. A warmer climate can also increase the propagation of vector-borne and other infectious diseases. Approximately $9.9 \%$ of households headed by women will be directly affected by climate change. ${ }^{12}$ Supplying clean and modern energy services to the rural community and disaster-prone areas can mitigate the vulnerability. To effectively do this, it would help to understand indigenous knowledge and practices on disaster early warning and management (Box 1).

\section{Box 1: Indigenous or Local Knowledge on Disaster Resilience}

Housing structure and early warning techniques are among the ways small coastal communities deal with natural catastrophes. For example, some of the houses are built with cho-chala (four-sided roofs), which protects houses from strong wind from all directions. These types of roofs have a lower height than twosided roofed houses. Another technique is building a core house inside the main house, where people keep their important possessions, and which is more likely to remain standing after a disaster.

People in the coastal and flood-prone areas try to build their house on higher land with water unable to reach to the upper plinth level. During disasters, people take shelter on the embankment area for their safety and that of their domestic animals and household possessions. The government and coastal communities are planting trees on the banks of rivers to reduce the impact of cyclones.

Small ethnic groups also observe the behavior of animals and insects (for example, ants, fish, dogs, and frogs) and use them as early disaster warning. For example, high number of ants and jumping behavior of fish indicate heavy rain and non-flying movement of termites is a sign of a prolonged dry season. Other examples of local knowledge include obtaining information from the weather, for example, types of clouds and direction of wind (Nowreen and Mohiuddin 2017). There is no scientific explanation for some of these correlations, but they have been used widely by communities and help to build their resilience.

Source: S. Nowreen and Md. Mohiuddin. 2017. An Assessment on Application of Indigenous Knowledge as Disaster Risk Reduction Strategies in Kutubdia, Cox's Bazaar, Bangladesh. Dhaka University Journal of Science. 65 (2). 125-131.

10 A. K. Ghosh. 2019. "Community Energy Resilience: Framing the Issues and Identifying Social Metrics." ADB Conference on Inclusive Energy Resilience in Bangladesh. Gazipur, Bangladesh, 23 April 2019.

11 Z. Sharmin and M.S. Islam. 2013. Consequences of Climate Change and Gender Vulnerability: Bangladesh Perspective. Falls Church: Bangladesh Development Research Center (BDRC).

12 M. Mani et al. 2018. South Asia's Hotspots : Impacts of Temperature and Precipitation Changes on Living Standards. South Asia Development Matters. Washington, DC: World Bank. 


\section{Gender and Intersecting Vulnerabilities and Community Resilience}

5. Although women are mainly responsible for arranging energy for domestic use and managing various types of energy use and assessing the needs of energy at the household level, they have less decision-making power in choosing energy sources and technologies and limited control over resources. Women face a burden of unpaid labor such as cleaning houses, taking care of children and elderly or disabled people, cooking, poultry raising, and helping in dairy farming. They have limited access to education, health services and nutrition, information on available technologies, and financial resources and services, and have restrictions on mobility.

6. Small ethnic groups have very limited access to electricity as they mainly live in remote locations, and lack of information on existing technologies and the availability of financial support from different agencies. The delays in securing an electricity connection and the inability of poor and marginalized groups to pay, are being addressed by the government through "Alor Feriwala" programs, which provide immediate and free electricity connection to customers using mobile technical units. Electricity tariffs to households are structured as increasing block tariffs, providing life-line rates for low users, to enable poor customers to continue to use electricity at subsidized rates.

7. Some important work has been undertaken to analyze gender issues and mainstream gender in strategies to strengthen community resilience to climate-related disasters. Advancing women's participation in household decision-making, community organizations, and markets is critical to building resilience for themselves, their families, and their communities. ${ }^{13}$ Case studies on Bangladesh also found 'intersecting vulnerabilities' which means that some groups of women (poor, elderly, widows) are more likely to have no access to food and good quality water. Resilience, as commonly understood, has been assessed as an inadequate framework for understanding the intersecting vulnerabilities that women face due to embedded socio-cultural norms. ${ }^{14}$

\section{Box 2: Gender Equality and Social Inclusion in ADB-Assisted Disaster Risk Management Projects}

The Asian Development Bank (ADB) promotes the integration of gender equality objectives in assisted projects, which has facilitated the adoption of key resilience qualities, such as inclusiveness, reflectiveness, flexibility, and resourcefulness (ADB 2018). ADB projects in Bangladesh, such as the Coastal Towns Environmental Infrastructure Project, Flood and Riverbank Erosion Risk Management Investment Program, Coastal Climate-Resilient Infrastructure Project, Rupsha 800-Megawatt Combined Cycle Power Plant Project, and Emergency Assistance Project (related to a humanitarian crisis triggered by an influx of displaced persons from Myanmar) include gender action plans (GAPs) or gender equality target results. These GAPs or targets focus on gender-responsive disaster risk reduction and management and climate change adaptation; enhancing the resilience capacity (with a gender focus) of the local government and communities; improving women's participation in consultation and monitoring bodies; employment of women in both skilled and unskilled labor; construction and upgrading of women-friendly cyclone shelters; training women and men in the safe and productive use of electricity; improving access to clean water; street lighting to improve women's safety and mobility; construction and upgrading of market spaces for women's livelihoods; and improving cookstoves to reduce indoor air pollution. Indicators to monitor these actions and target results have also been included.

Source: ADB.

13 A. Anderson et al. 2018. Measuring Gender Dynamics in Resilience: Tools for integrating gender into resilience-focused programs. Portland, OR: Mercy Corps.

14 J. C. Jordan. 2019. Deconstructing resilience: why gender and power matter in responding to climate stress in Bangladesh. Climate and Development. 11 (2). pp. 167-179. 


\section{Policies, Strategies and Programs}

8. The 2004 National Energy Policy highlighted the importance of providing cooking energy. The 2008 Renewable Energy Policy supports the development of cooking fuels or technologies such as biogas, improved cookstoves, solar electrification systems for households and community use, and other renewable energy technologies that directly benefit women. The 2013 Action Plan for Energy Efficiency and Conservation takes into consideration the impact of improved energy efficiency at the household level and the need for raising public awareness. The 500-megawatt (MW) Solar Program of 2013 will enhance the quality of life of the population and reduce drudgery for women by bringing electrification to unelectrified areas. ${ }^{15}$ (Appendix B).

9. In its vision statement, the Bangladesh Rural Electrification Board states "Electricity for all by 2021." The electrification rate is measured by the number of household connections that are activated. Although different definitions are used by utilities to measure the coverage of their distribution network, the Power Division of the Ministry of Power, Energy and Mineral Resources ${ }^{16}$ uses the following definition for the electrification rate:

$$
\text { Electrification rate } \%=\frac{\# \text { Residential connections } \times \text { Family number parameter }+\# \text { SHS } \times 4}{\text { Total population }}
$$

Where:

\# Residential connections mean the number of active electricity accounts classified as households

The family number parameter ranges between 4.5 to 6.5 , which is an estimate of the average number of individuals that are served by a single connection.

\# SHS means the number of solar home systems, which operate off-grid. Four people on average are considered to be served by a single SHS.

10. The Disaster Management Act 2012 provides a preference for ultra-poor and underprivileged communities (tribal groups, small ethnic groups, and anthropological communities that are deprived of socio economic and other facilities), especially older persons, women, children and persons with disabilities, to be given protection. ${ }^{17}$ In 2012, Bangladesh set up a Department of Disaster Management under the Ministry of Disaster Management and created a National Plan for Disaster Management 2010-2015 and a "Bangladesh Climate Change Strategy and Action Plan 2009" built around six pillars: (i) food security, social protection, and health; (ii) comprehensive disaster management; (iii) infrastructure; (iv) research and knowledge management; (v) mitigation and low-carbon development; and (vi) capacity building.

11. The Government of Bangladesh leads the implementation of Cyclone Preparedness Programs for early warning system development and the National Resilience Program to (a) improve nationallevel capacity for risk-informed, gender-responsive, and disability-inclusive development planning; (b) strengthen national capacity to address disasters, including those of exceptional magnitude due to climate change, in a gender-responsive and disability-inclusive manner; (c) improve the capacity of selected public institutions to achieve resilient outcomes through risk-informed, gender-responsive infrastructure systems; (d) enhance women's leadership capacity for gender-responsive national and local disaster management decision-making, investment, and policy; (e) strengthen community-level preparedness, response, and recovery capacity for disasters.

15 N. Selim. 2019. National Policies in the Energy Sector and Their Gender Features. ADB Conference on Inclusive Energy Resilience in Bangladesh. Gazipur, Bangladesh, 23 April 2019.

16 Government of Bangladesh, Ministry of Power, Energy and Mineral Resources, Power Division, Power Cell. 2021. Bangladesh Power Sector at a Glance. Dhaka.

17 Government of Bangladesh. 2012. Act No. 34 of the year 2012. Bangladesh Gazette. Dhaka: Bangladesh National Parliament. 


\section{APPENDIX B: BANGLADESH: ENERGY POLICY AND GENDER CONSIDERATIONS}

\begin{tabular}{|c|c|}
\hline Main Policy or Documents in the Energy Sector & Directly Addresses Women's Energy Needs \\
\hline National Energy Policy 2004 & $\begin{array}{l}\text { Yes. The importance of provision for cooking energy is } \\
\text { highlighted. }\end{array}$ \\
\hline Power Pricing Framework 2004 & No \\
\hline Private Sector Power Generation Policy (revision 2004) & No \\
\hline $\begin{array}{l}\text { Policy Guidelines on Power Purchase from Captive Power } \\
\text { Plant } 2007\end{array}$ & No \\
\hline Remote Area Power Supply Systems Fund 2007 & $\begin{array}{l}\text { Yes. It promotes investment to facilitate electricity supply to } \\
\text { households in remote areas. }\end{array}$ \\
\hline Renewable Energy Policy 2008 & $\begin{array}{l}\text { Yes. The policy supports the development of cooking fuels } \\
\text { or technologies like biogas, improved cookstoves, solar } \\
\text { electrification systems for households and community use, } \\
\text { and other renewable energy technologies, which are to } \\
\text { directly benefit women in their day-to-day activities. }\end{array}$ \\
\hline $\begin{array}{l}\text { Bangladesh Private Sector Infrastructure Guidelines } \\
\text { (revision November 2008) }\end{array}$ & No \\
\hline Small Power Plant Policy & No \\
\hline $\begin{array}{l}\text { Policy Guidelines for Enhancement of Private Participation } \\
\text { in the Power Sector, } 2008\end{array}$ & No \\
\hline Power System Master Plan 2010 & No \\
\hline Action Plan for Energy Efficiency and Conservation, 2013 & $\begin{array}{l}\text { Yes. All the sections take into consideration the impact of } \\
\text { improved energy efficiency at the household level and the } \\
\text { need for taking action for raising awareness. }\end{array}$ \\
\hline Solar Guidebook 2013 & $\begin{array}{l}\text { Yes. Women will benefit from solar electrification, irrigation, } \\
\text { and other technologies. }\end{array}$ \\
\hline Country Action Plan for Clean Cookstoves, 2013 & $\begin{array}{l}\text { Yes. It attaches priority to reduced household air pollution, } \\
\text { improved maternal and child health, and women's economic } \\
\text { empowerment through participation in cookstove-related } \\
\text { entrepreneurship. }\end{array}$ \\
\hline 500 MW Solar Program, 2013 & $\begin{array}{l}\text { Yes. Solar electrification in unelectrified areas will enhance } \\
\text { the quality of life of the population and reduce drudgery } \\
\text { for women. }\end{array}$ \\
\hline $\begin{array}{l}\text { National Policy for the Advancement of Women by the } \\
\text { Ministry of Women and Children Affairs }\end{array}$ & No \\
\hline
\end{tabular}

Source: ADB. 2017. Bangladesh Gender Equality Diagnostic of Selected Sectors. Manila. p. 68. 


\section{APPENDIX C: INDICATIVE VULNERABILITY ASSESSMENT METHODOLOGY}

1. To quantify the power system vulnerability, it is proposed to assign numerical scores for each of these criteria; a subsequent scale is generated that aggregates all criteria on a scale from 1 to $n$. The scale size $\mathrm{n}$ needs to be determined according to the precision of the data available, the degree of detail required from the analysis, and the intended applications (high-level decision-making, technical discussion, etc.). Historical data may also further guide the definition of such scales.

2. Two methods can be adopted to populate the values. For an initial high-level assessment with limited data available, one system parameter is selected among the four parameters referred above and will be the focus of the analysis. This parameter is rated by a score on a scale from 1 to $n$, while other parameters with fewer data available may be considered as "Bonus Points" or "Malus Points" modifying the rating upward or downward (while capping the values to the extremity of the scale). Further in this section, Table A3.2 will exemplify the scenario where only the robustness of the system is taken as the main parameter, while others are bonus/malus variables notching the overall rating upward or downward.

3. The scoring from 1 to $\mathrm{n}$ can be seen as a mark given, based on a broad assessment of the overall characteristics of the electricity distribution network (e.g., answering questions such as: "On a scale from one to five, based on your knowledge of the electricity distribution system characteristics in *specific geographic area*, how would you rate the overall smartness of the system?"). For more reliability, these ratings can also be aggregated based on the feedback received from various field technicians and specialists. Alternatively, the scoring scale can be matched against a set of vulnerability classes for the system where each score from 1 to $\mathrm{n}$ is associated with a range of the parameter's variability, as exemplified in Table A3.1a and Table A3.1b. Examples of questions for such rating can be:

On average, what is the proportion of assets in ${ }^{*}$ specific geographic area, ${ }^{*}$ which have been reinforced for * specific disaster ${ }^{*}$ resilience?

- $\quad$ On average, how long would you anticipate the overall distribution system downtime in *specific geographic area* to last for, if hit by a *specific disaster*?

Table A3.1: Examples of Classes Associated with Rating Scales

\begin{tabular}{|c|c|}
\hline $\begin{array}{c}\text { a. Robustness } \\
\text { rating scale }\end{array}$ & $\begin{array}{c}\text { Percentage of } \\
\text { reinforced assets }\end{array}$ \\
\hline 1 & $80-100 \%$ \\
\hline 2 & $60-80 \%$ \\
\hline 3 & $40-60 \%$ \\
\hline 4 & $20-40 \%$ \\
\hline 5 & $0-20 \%$ \\
\hline
\end{tabular}

\begin{tabular}{|c|c|}
\hline $\begin{array}{c}\text { b. Recovery time } \\
\text { rating scale }\end{array}$ & $\begin{array}{c}\text { Downtime: } \\
\text { up to ... days }\end{array}$ \\
\hline 1 & 2 \\
\hline 2 & 7 \\
\hline 3 & 14 \\
\hline 4 & 30 \\
\hline 5 & 90 \\
\hline
\end{tabular}

Note: As exemplified above, according to the focus of attention of the analysis and how demanding the analysis aims to be in terms of disaster resilience, the vulnerability classes defined may or may not be linear.

Source: Authors. 
Table A3.2: Example of Rapid Rating for Power System Vulnerability

\begin{tabular}{cccccc}
\hline & $\begin{array}{c}\text { Power system } \\
\text { Robustness }\end{array}$ & $\begin{array}{c}\text { Degree of } \\
\text { redundancy }\end{array}$ & $\begin{array}{c}\text { Smartness of } \\
\text { the system }\end{array}$ & $\begin{array}{c}\text { Speed of repairs } \\
\text { and recovery }\end{array}$ & $\begin{array}{c}\text { Overall vulnerability } \\
\text { rating }\end{array}$ \\
\hline Geographical Area 1 & $1-\mathrm{n}$ & notch-up or down & notch down & notch-up or down & $1-\mathrm{n}$ \\
\hline Geographical Area 2 & $1-\mathrm{n}$ & notch-up or down & notch down & notch-up or down & $1-\mathrm{n}$ \\
\hline Geographical Area 3 & $1-\mathrm{n}$ & notch-up or down & notch down & notch-up or down & $1-\mathrm{n}$ \\
\hline ... & $1-\mathrm{n}$ & notch-up or down & notch down & notch-up or down & $1-\mathrm{n}$ \\
\hline
\end{tabular}

Robustness is taken as the main parameter. Scale considered is 0 to $n$, where $\mathrm{n}$ is the highest vulnerability score and 0 the lowest (most resilient). ${ }^{18}$

Source: Authors.

4. If sufficient data is available and a high degree of detail expected, not only may each parameter receive a 1-n rating of its own, but the rating may be applied to each asset within the system and then aggregated together into system-wide ratings. All four parameters would then be factored together according to the same weighting factors:

$\frac{\text { Robustness mark (1 to } n)}{n} \times \frac{\text { Redundancy mark (1 to } n)}{n} \times \frac{\text { Smartness mark (1 to } n)}{n} \times \frac{\text { Recovery time mark (1 to } n)}{n}$

Note: If sufficient details are available, percentages could be used instead of a $0-n$ scale.

If more attention needs to be given to a specific parameter (for example, the response time), then different weighting factors can be used, as shown in Table A3.3.

Table A3.3: Example of Integration of Parameters with Different Weighting

\begin{tabular}{lcc}
\hline Parameter & Rating & Coefficient \\
\hline Robustness & 1 to 5 & 1 \\
\hline Redundancy & 1 to 5 & 1 \\
\hline Smartness & 1 to 5 & 1 \\
\hline Fast recovery & 1 to 5 & 2 \\
\hline
\end{tabular}

Source: Authors.

In this case, the overall power system vulnerability may be calculated as: $\frac{\sum \text { Rating }_{i} \times \operatorname{Coef}_{i}}{\Sigma \operatorname{Coef}_{i}}$

(The above value is given as a rating between 0 and 1 (equivalent to percentages); the latter can be remultiplied by $n$ if $1-n$ rating desired).

18 The way this table is to be read is that a rating is given to the robustness of the distribution system (based on the proportion of its individual components which have been reinforced to withstand extreme weather events). Subsequently, the existence of redundancy in the upstream network (mainly from the feeding transmission lines), may notch up or down the stand-alone vulnerability of the distribution system in each specific region, thus taking into consideration the configuration of the upstream feeding network. Similarly, if the "smartness" of a local distribution system (or individual households) gives it capability to operate in islanding mode, this would notch down the stand-alone vulnerability of the system. Same goes for the response preparedness and ease of maintenance for the existing equipment. 


\section{A. Community Vulnerability Assessment}

5. To assess the overall vulnerability to disaster, featuring in the calculation of the Energy Loss Risk, the second vulnerability to be quantified, besides the vulnerability of the power system to disasters, is the vulnerability of the community to power system failure and loss of energy access. This latter vulnerability depends on multiple criteria, such as:

i. Socio economic resourcefulness of households and upazilas;

ii. Availability of early warning systems and shelters equipped with stand-alone power generation capabilities;

iii. Access to information and communication (e.g., radio, TV, mobile phones, internet);

iv. Availability of local skilled labor to repair and restore the electricity distribution system autonomously;

v. Availability of alternative sources of energy that can meet the basic life, farming, business, and other livelihood requirements while the grid electricity supply is being restored;

vi. Access to services (government, private sector, and/or NGO-provided);

vii. Access to markets; and

viii. Governance, or capacity of local government institutions-from upazila to district-levelto deliver necessary gender equality and social inclusion (GESI)-responsive information and services.

6. To assess the community vulnerability, a GESI analysis of these criteria is to be performed, identifying potential exacerbating factors for communities with a higher proportion of vulnerable socioeconomic groups, such as below-poverty-line single women, widows, and small ethnic groups. The aim is to ensure the continuity of power supply during a disaster event and throughout the recovery period for the communities, inclusive of their most vulnerable members, beyond the mere provision of household lighting, by providing optimal electricity consumption levels that can be continuously leveraged for local economic development, mainstreaming women's welfare and economic empowerment.

7. As referred earlier, for consistency purposes, the community vulnerability assessment and associated quantified ratings must be carried out on the same geographic basis as the power system vulnerability assessment and ratings provided above.

8. The community resilience criteria considered in this research are summarized in Table A3.4. These criteria are correlated to the sociodemographic indicators identified in Table 2. Target values according to which a community is considered to have met these indicators for disaster resilience purposes are still to be defined, based on field surveys, historic data in particular from communities that have faced such disasters in the past, as well as community consultations. In particular, it is proposed to survey selected communities that have been impacted recently by extreme weather events, to match the target indicators to perceived and measured vulnerability after a disaster. For now, the following section describes the methodology to be applied, when such quantified targets are known. 
Table A3.4: Community Resilience Criteria and Indicators

\begin{tabular}{|c|c|}
\hline Main Criteria & Indicators and Metrics \\
\hline \multirow[t]{3}{*}{ Economic (E) } & - Cash income (Ca) \\
\hline & - Land ownership and/or use (L) \\
\hline & - Productive assets ownership and/or access and use (Pa) \\
\hline \multirow[t]{2}{*}{ Knowledge (K) } & - Education \\
\hline & - Technical and/or skills training \\
\hline \multirow[t]{5}{*}{ Information and Communication (I) } & Ownership or access to: \\
\hline & - Television \\
\hline & - Radio \\
\hline & - Internet \\
\hline & - Computers \\
\hline \multirow[t]{4}{*}{ Technology and Infrastructure (T) } & Availability and access to: \\
\hline & - Early warning systems \\
\hline & - Power generation assets \\
\hline & - Shelters \\
\hline \multirow[t]{4}{*}{ Governance (G) } & - Capacity \\
\hline & - Information management \\
\hline & - Service delivery \\
\hline & - GESI awareness \\
\hline \multirow[t]{2}{*}{ Women's time poverty $(\mathrm{W})$} & - Access to pumped water \\
\hline & $\begin{array}{l}\text { - Power for food processing equipment and medium } \\
\text { power appliances. }\end{array}$ \\
\hline
\end{tabular}

Source: Authors.

9. Based on the above, community resilience is quantified by assessing the degree to which the indicators associated with the above criteria are fulfilled. Similar to the power system resilience valuation, it is proposed that community resilience be quantified along a scale. Just as for power systems resilience, two methods can be adopted to populate the values, according to the degree of precision and depth required from the analysis.

10. For an initial high-level valuation, a three-level scale is suggested:

i. If more than four criteria are substantially fulfilled (a criterion is considered substantially fulfilled if over two-thirds of the indicators for this criterion have reached their resilience-level target) the community is considered resourceful and able to anticipate the event, adopt protection measures and recover relatively autonomously; the latter is therefore ranked with Low Vulnerability;

ii. If three criteria are substantially fulfilled, the community is ranked as demonstrating Medium Vulnerability.

iii. If two or fewer criteria are fulfilled, the community is deemed "dependent," having little to no capacity to anticipate or protect itself from the event; it is therefore ranked as having High Vulnerability. 
11. If further precision is desired, it is proposed to resort to a more extended scale from 1 to $\mathrm{m}$. To each indicator, there will be an associated percentage of achievement. These percentages are aggregated for all indicators related to one criterion (as referenced in Table 2). As per the three-level scale above but now with a more extended scale, each community is to be ranked according to one of the $m$ classes, from 0 being the least vulnerable to $m$ being most vulnerable, as exemplified in Figure A3.1. The desired number of classes $(\mathrm{m})$ would be determined based on the precision of the data available, the degree of detail required from the analysis, and the intended applications (high-level decision-making, communityrelated applications, etc.) and can be guided following further collection and analysis of field data across communities.

Figure A3.1: Community Vulnerability Classes (arbitrary example with $\mathbf{m = 5}$ )

\begin{tabular}{|c|c|c|c|}
\hline & \multicolumn{3}{|c|}{ Community Vulnerability Scale (Indicative) } \\
\hline vulnerable & 2 & 4 & resilient \\
\hline $\begin{array}{l}\text { Vulnerable: } \\
\text { Very little or no capacity to anticipa } \\
\text { severe events. Very dependent on ext } \\
\text { recover. }\end{array}$ & $\begin{array}{l}\text { nd mitigate } \\
\text { I support to }\end{array}$ & $\begin{array}{l}\text { Can anticip } \\
\text { and recover }\end{array}$ & $\begin{array}{l}\text { Resilient: } \\
\text { events, adopt protective measures, } \\
\text { ckly and relatively autonomously. }\end{array}$ \\
\hline
\end{tabular}

Source: National Institute of Standards and Technology Smart Grid Framework R3.

12. Some indicators (within criteria valuation) or some criteria (for the overall vulnerability valuation) may present more importance than others or one may wish to see specific ones further stressed. It is therefore possible to associate weights to each indicator and/or criterion. It is advised that the prioritization or "stressed importance" of these criteria be determined by the community itself, to ensure that the methodology conveys and dutifully addresses community needs and not arbitrarily defined targets. It is therefore advised to define these weights through a participatory consultation process based on methodologies such as focus group discussions and the gathering of stories, with a specific focus on the communities and target groups identified as particularly vulnerable. Through this methodology, a final community resilience "composite index" can also be calculated as:

\section{$\left\{\sum\right.$ (indicator value (as percentage) $*$ Weight associated to this indicator $\left.)\right\} / \sum$ (Weights).}

13. To further this aim, the surveying and monitoring of a selected community is recommended over a significant period of time to further refine this valuation methodology, to best reflect the challenges and needs of the communities. It is recommended that data gathered would be disaggregated by sex, social inclusion, and vulnerability. The preparation of a test project, as recommended in section $\vee$ and elaborated in section $\mathrm{VI}$, would be very valuable to the continuous refining of the methodology briefly presented here.

\section{B. Aggregated Vulnerability}

14. The overall vulnerability to extreme weather events in a selected geographical area is the combination of the power grid assets vulnerability and local community vulnerability. The $\mathrm{n}$ grid vulnerability classes and the $m$ community vulnerability classes described above can be aggregated through a double-entry table referred to as an aggregated scoring matrix as exemplified in Figure A3.2. 
Figure A3.2: Example of Aggregated Vulnerability Scoring Matrix (with $n=7$ and $m=5$, both arbitrary)

\begin{tabular}{|c|c|c|c|c|c|c|}
\hline & & \multicolumn{5}{|c|}{ Community Vulnerability } \\
\hline \multirow{8}{*}{ 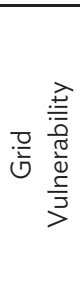 } & & Class 1 & Class 2 & Class 3 & Class 4 & Class 5 \\
\hline & Class 1 & 0.01 & 0.05 & 0.2 & 0.5 & 0.75 \\
\hline & Class 2 & 0.05 & 0.1 & 0.3 & 0.6 & 0.8 \\
\hline & Class 3 & 0.2 & 0.3 & 0.6 & 0.75 & 0.9 \\
\hline & Class 4 & 0.5 & 0.6 & 0.75 & 0.9 & 0.95 \\
\hline & Class 5 & 0.75 & 0.8 & 0.9 & 0.95 & 1 \\
\hline & Class 6 & 0.75 & 0.8 & 0.9 & 0.95 & 1 \\
\hline & Class 7 & 0.8 & 0.9 & 0.9 & 0.95 & 1 \\
\hline
\end{tabular}

Source: Authors.

15. The aggregated vulnerability can be a scalar number between 0-1 that is input in the calculation of the Energy Risk Impact (section 4.2). Similar to community and grid vulnerability, the aggregated vulnerability itself can also be subdivided into discrete classes. For example, three classes: Low, Medium, and High vulnerability (green, orange, and red in Figure A3.2). A "Low Vulnerability" class would be the desired state for each community, corresponding to the combinations of community vulnerability and grid vulnerability that are deemed desired and satisfactory for high resilience to disaster. Conversely, the "High Vulnerability" class would indicate the need for priority action for those communities. Both vulnerability components (grid and community) can be separately or jointly addressed with specific measures to reduce their aggregated value. This is the key lever that government and planners can use to mitigate the impact of extreme weather events on the continuous quality power supply to vulnerable communities. 


\section{APPENDIX D: ENERGY LOSS RISK EQUATION ${ }^{19}$ AND POWER SYSTEM PLANNING RESILIENCE OPTIMIZATION}

1. Energy Loss Risk (ELR) is a measure of the loss of energy from extreme weather events across a territory. It is calculated according to:

$$
E L R(k W h)=\sum_{\substack{\text { Distaster } \\ \text { Types }}}\left(\int_{\text {Territory }}\left(\text { Probability }_{\text {disaster }} \times \text { Vulnerability } \times \text { Exposure }\right) d s\right)
$$

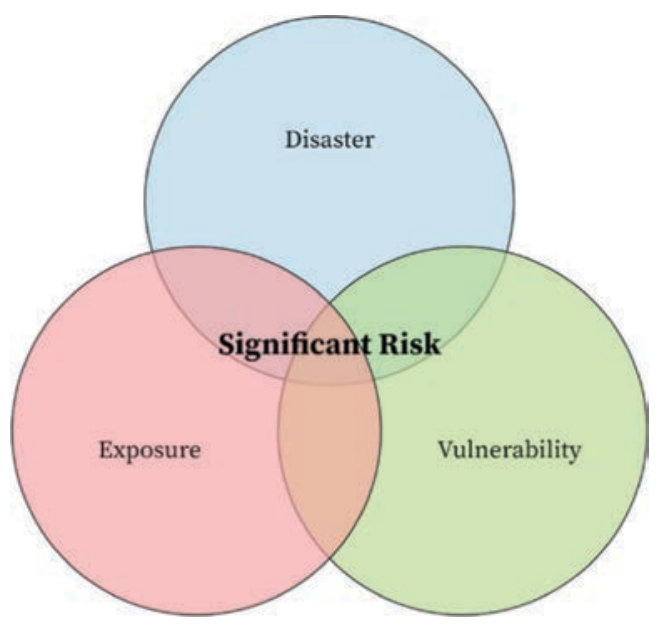

2. Exposure or "Energy Not Supplied" Estimation represents the total amount of energy that would not be served due to a weather event. This measure varies for each geographical area and can be estimated by multiplying the average daily usage of energy by the local population by the expected number of days before restoration. That last number can be extrapolated from the "Vulnerability Scale" matrix following the assessment of the local power system vulnerability.

3. Assignment of a Monetary Value to the Energy Loss Risk Impact. It is proposed to assign a monetary value to the ELR to enable a homogeneous and coherent linkage between the ELR and investments needed to minimize it. By definition, the ELR is a risk-weighted measure of an amount of energy not served, expressed in kilowatt-hour ( $\mathrm{kWh}$ ). By association, it can be argued that the energy risk impact value that is a measure of energy not supplied in response to extreme weather events carries a similar negative impact on the gross domestic product (GDP), enabling the calculation of the monetary cost of that energy risk impact.

19 For example, in the credit risk practice, the expected loss (EL) for a loan is calculated based on the probability of default $(P D)$, the loss given default (LGD) that takes into consideration any collateral given in guarantee for secured loans that can be recovered and the exposure at default (EAD) or the outstanding amount due, that is as PD $\times$ LGD $\times$ EAD. The expected loss for the bank over the next year will be the sum of each credit's expected loss for every credit type. Similarly, the energy-demand response (EDR) aggregates all the potential energy not served over the entire territory for each potential extreme weather event. To minimize their EL, the banks would select more creditworthy customers and collect more liquid collaterals to mitigate the effect of default. Similarly, to minimize the energy risk (and hence the expected energy loss if disaster occurs), it is advised to invest in more resilient power systems, which is what this methodology aims to support. 
4. Resilience Optimization. Resilience optimization can be summarized as follows:

\section{Equation 1: Resilience Optimization and Power System Planning}

$$
\begin{aligned}
\min _{x_{i}(s)}\left(E L R_{s, W}\left[V\left(x_{i}(s)\right), \operatorname{EnS}\left(x_{i}(s)\right)\right]\right) \\
\text { such that, } \\
{\left[\sum_{i \in A}\left(c_{i}(s) \cdot x_{i}(s)\right)\right] \leq \text { Budget } } \\
x_{i}(s) \in\{0,1\} \forall i \in A, \forall s \in S
\end{aligned}
$$

5. Where $\mathrm{S}$ is the total geographical area, $\mathrm{s}$ is a region in $\mathrm{S}, \mathrm{W}$ is the entire set of weather events considered (e.g., cyclone, flood, summer storm, etc.), $w$ is a weather element type in W, A is the set of possible enhancement of robustness of grid assets (e.g., flood barrier, etc.), $x_{i}(s)$ is a grid robustness enhancement that is considered to be installed in region $s, E_{S, w}$ is the Energy Loss Risk in the configuration of the grid where assets $x_{i}(s)$ are in place if a weather event $w$ happens in region $s, V\left(x_{i}(s)\right)$ is the aggregated vulnerability in the configuration where candidate asset $x_{i}(s)$ are in place in region $s$, $\operatorname{EnS}\left(x_{i}(s)\right)$ is the energy not supplied in the configuration where candidate asset $x_{i}$ are in place in region $s, c_{i}(s)$ is the cost of investment associated with candidate asset $x_{i}$ to be installed in region $c$ and Budget represents the total amount of money available to be invested in resilient network enhancement. That budget can be compared with the pseudo monetary value of the energy demand response, or EDR, reduction that is gained through the resilience investment. 


\section{REFERENCES}

Asian Development Bank (ADB). 2015. Bangladesh: Enabling Poor Women's Benefits from Enhanced Access to Energy in Hatiya Island. Manila.

ADB. 2017. Bangladesh Gender Equality Diagnostic of Selected Sectors. Manila

ADB. 2017. Poverty Data: Bangladesh. Manila.

ADB. 2018. Scaling Up Resilience-Building Measures through Community-Driven Development Projects: Guidance Note. Manila.

ADB. 2020. Bangladesh: Power System Efficiency Improvement Project. Manila.

Asuduzzaman, M. 2013. Electricity Consumption and Economic Growth in Bangladesh: Co-integration and Causality Analysis. Research Study Series No. - FDRS 02/2013. Dhaka: Ministry of Finance, Government of Bangladesh.

Asaduzzaman, M. et al. 2014. Surge in Solar-Powered Homes - Experience in Off-Grid Rural Bangladesh. Washington, DC: World Bank Group.

Bijker, W. E. and J. Law, eds. 1992. Shaping Technology/Building Society: Studies in Sociotechnical Change. Cambridge, Massachusetts: MIT Press.

Chow, J. et al. 2003. Energy resources and global development. Science. 302 (5650). pp. 1528-1531.

Climate Change Cell. 2008. Climate Change, Gender and Vulnerable Groups in Bangladesh. Dhaka: Government of Bangladesh, Ministry of Environment and Forests.

Electric Energy System Research Institute (EPRI). 2016. Electric Power System Resiliency: Challenges and Opportunities. Palo Alto.

ENERGIA, World Bank/ESMAP and UN Women. 2018. Accelerating SDG 7 Achievement Policy Brief 12: Global Progress of SDG 7-Energy and Gender. New York: United Nations.

Espinoza, S. et al. 2017. Seismic resilience assessment and adaptation of the Northern Chilean power system. IEEE Power and Energy Society General Meeting.

Government of Bangladesh. 2017. Data Gap Analysis for Sustainable Development Goals (SDGs) Bangladesh Perspective. Dhaka.

Government of Bangladesh. 2017. Eradicating Poverty and Promoting Prosperity in a Changing World. UN Sustainable Development Goals Program - Bangladesh Voluntary National Review (VNR). Dhaka.

Government of Bangladesh, Bangladesh Power Development Board (BPDP). 2020. Annual Report, 2019-2020. Dhaka.

Government of Bangladesh, Ministry of Environment and Forests (MOEF). 2015. Intended Nationally Determined Contributions (INDC). Dhaka. 
Government of Bangladesh; Ministry of Power, Energy and Mineral Resources. 2016. Power System Master Plan 2016. Dhaka.

Government of Bangladesh; Ministry of Power, Energy and Mineral Resources. 2018. Revisiting Power System Master Plan (PSMP) 2016. Dhaka

Government of Bangladesh, Ministry of Power, Energy and Mineral Resources, Power Division, Power Cell. 2021. Bangladesh Power Sector at a Glance. Dhaka: Bangladesh National Portal.

Government of Bangladesh, Sustainable and Renewable Energy Development Authority. 2021. Statistics of Installed Net Metering System. Dhaka: Bangladesh National Portal.

Grubler, A. 2012. Grand Designs: Historical Patterns and Future Scenarios of Energy Technological Change. Historical Case Studies of Energy Technology Innovation. In Aguayo et al., The Global Energy Assessment. Cambridge, UK: Cambridge University Press.

Habiba, Abedin, and Shaw. 2013. Disaster Education in Bangladesh: Opportunities and Challenges. In Shaw et al. Disaster Risk Reduction Approaches in Bangladesh. Basel: Springer.

Integrated Research and Action for Development. 2018. Assessment of Socio-economic Impacts of CBET in Bangladesh. Delhi.

Jordan, J. C. 2019. Deconstructing resilience: why gender and power matter in responding to climate stress in Bangladesh. Climate and Development. 11 (2). pp. 167-179.

Kabeer, N. 2012. Women's economic empowerment and inclusive growth: labour markets and enterprise development. SIG working paper 2012/1. Ottawa: International Development Research Centre (IDRC).

Khandker, S.R. 2009. Welfare Impacts of Rural Electrification-A Case Study from Bangladesh. World Bank Policy Research Paper 4859. Washington, DC: World Bank.

Kreft, S., D. Eckstein, L. Dorsch, and L. Fischer. 2015. Global Climate Risk Index 2016. Bonn: Germanwatch. https://germanwatch.org/sites/germanwatch.org/files/publication/13503.pdf.

Mani, M. et al. 2018. South Asia's Hotspots: Impacts of Temperature and Precipitation Changes on Living Standards. South Asia Development Matters. Washington, DC: World Bank

Martínez, C. et al. 2018. Techno-economic and business case assessment of multi-energy microgrids with co-optimization of energy, reserve and reliability services. Applied Energy. 210. pp. 896-913.

Masuduzzaman, M. 2013. Electricity Consumption and Economic Growth in Bangladesh: Co-integration and Causality Analysis. Research Study Series No. - FDRS 02/2013. Dhaka: Government of Bangladesh, Ministry of Finance.

Mehedi, H. et al. 2018. Bhola IPP and its Impact on Local Communities: Voices from the Ground: A Civil Society Study Report. Khulna: CLEAN (Coastal Livelihood and Environmental Action Network) and Bangladesh Working Group on External Debt (BWGED).

Mitchell, T. and K. Harris. 2012. Resilience: A risk management approach. London: Overseas Development Institute. 
Mohideen, R. 2018. Energy Technology Innovation in South Asia-Implications for Gender Equality and Social Inclusion. Working Paper Series. No 61. Manila: Asian Development Bank.

National Institute of Standards and Technology. 2014. NIST Framework and Roadmap for Smart Grid Interoperability Standards, Release 3.0. Washington, DC: U.S. Department of Commerce.

Nowreen and Mohiuddin. 2017. An Assessment on Application of Indigenous Knowledge as Disaster Risk Reduction Strategies in Kutubdia, Cox's Bazaar, Bangladesh. Dhaka University Journal of Science. 65 (2). pp. 125-131

Nussbaum, M. 2000. Women and human development: The capabilities approach. Cambridge, UK: Cambridge University Press.

Nussbaum, M. 2011. Creating Capabilities: The human development approach. Cambridge, Massachusetts: Harvard University Press.

Panteli, M. and P. Mancarella. 2015. The Grid: Stronger, Bigger, Smarter? Presenting a Conceptual Framework of Power System Resilience. IEEE Power and Energy Magazine. 13 (3). pp. 58-66.

Panteli, M. and P. Mancarella. 2017. Modelling and Evaluating the Resilience of Critical Electrical Power Infrastructure to Extreme Weather Events. IEEE Systems Journal. 11 (3). pp. 1733-1742.

Panteli, M. et al. 2017. Power System Resilience to Extreme Weather: Fragility Modelling, Probabilistic Impact Assessment, and Adaptation Measures. IEEE Transactions on Power Systems. 32 (5). pp. 3747-3757.

Pitt, J. 2018. Democracy by Design. Amsterdam: Bitcoin Wednesday Conference.

Power Division, Ministry of Power, Energy and Mineral Resources, Bangladesh. 2018. Net Metering Guidelines 2018. Dhaka.

Roege, P. et al. 2014. Metrics for energy resilience. Energy Policy. 72. pp. 249-256.

Selim, N. 2019. National Policies in the Energy Sector and Their Gender Features. ADB Conference on Inclusive Energy Resilience in Bangladesh. Gazipur, Bangladesh, 23 April 2019.

Sen, A. 1979. "Equality of what?” Tanner lecture on human values, Stanford University, May 22.

Sen, A.. 2017. Collective Choice and Social Welfare-Expanded Edition. Cambridge, Massachusetts: Harvard University Press.

Shah, M. H. et al. 2015. Sustainability, Prospect and Challenges of Renewable Energy in Bangladesh. International Journal of Engineering and Innovative Technology. 5 (6). pp.63-69.

Syrri, A. and P. Mancarella. 2016. Reliability and risk assessment of post-contingency demand response in smart distribution networks. Sustainable Energy, Grids and Networks. 7. pp. 1-12.

Tabatabaei, M. et al (Eds.). 2019. Power Systems Resilience-Modeling, Analysis and Practice. Basel: Springer. https://www.springer.com/gp/book/9783319944418.

Taheripour et al. 2016. Economic and Land Use Impacts of Improving Water Use Efficiency in Irrigation in South Asia. Journal of Environmental Protection. 7 (11). pp. 1571-1591. 
Trakas, D. et al. 2019. Spatial Risk Analysis of Power Systems Resilience During Extreme Events. Risk Analysis. 39 (1). pp. 195-211. https://onlinelibrary.wiley.com/doi/epdf/10.1111/risa.13220.

Twigg, J. 2009. Characteristics of a Disaster-Resilient Community. Teddington, UK: DFID Disaster Risk Reduction NGO Interagency Group.

UNDP. 2014a. Resilient Bangladesh: UNDP Bangladesh Annual Report 2013-2014. Dhaka: UNDP Bangladesh. http://undp.org/content/dam/bangladesh/docs/Publications/UNDP_Annual_Report_2013_v28.pdf.

UNDP. 2014b. Sustaining Human Progress: Reducing Vulnerabilities and Building Resilience. Human Development Report 2014. New York.

UNDP. 2019. Beyond Income, Beyond Averages, Beyond Today: Inequalities in Human Development in the 21st Century. Human Development Report 2019. New York.

UN, Department of Economic and Social Affairs. 2015. Sustainable Development Goals. New York: United Nations. Sustainable Development Goals.

US Energy Information Administration (EIA). 2020. Electricity Consumption: International. Washington D.C.

Verzola, R. 2007. Crafting a sustainable energy program for the Philippines. Manila: Philippine Greens.

Vugrin, E. et al. 2017. Resilience Metrics for the Electric Power System: A Performance-Based Approach. Albuquerque: Sandia National Laboratories.

Wajcman, J. 2010. Feminist Theories of Technology. Cambridge Journal of Economics. 34 (1). pp. 143-152.

Watson, J. et al. 2014. Conceptual Framework for Developing Resilience Metrics for the Electricity, Oil, and Gas Sectors in the United States. Albuquerque: Sandia National Laboratories.

WePOWER. 2019. Pathways to Power: South Asia Region Baseline Assessment for Women Engineers in the Power Sector. Washington, DC: World Bank [unpublished].

World Bank. 2017. Building Climate Resilience into Power System Planning: The Case of Bangladesh. Washington, DC: World Bank.

World Bank. 2017b. World Bank Open Data. Access to electricity-Bangladesh. Washington, DC: World Bank.

World Bank. 2017c. World Bank Open Data. Access to electricity, rural-Bangladesh. Washington, DC: World Bank.

World Bank. 2019. A Shift Among Bangladesh's Power Planners. Washington, DC: World Bank. https://www.worldbank.org/en/news/feature/2019/02/21/a-shift-among-bangladeshs-power-planners.

World Bank. 2020. The World Bank In Bangladesh: Overview. Washington, DC: World Bank.

World Bank. South Asia Region. Pathways to Power: South Asia Region Baseline Assessment for Women Engineers in the Power Sector. unpublished. 
World Economic Forum. 2019. Global Gender Gap Report 2020. Geneva.

Wilhite, H. 2016. Gender Implications of Energy Use and Energy Access. Oxford: Applied Research Programme on Energy and Economic Growth (EEG). https://www.energyeconomicgrowth.org/sites/eeg. opml.co.uk/files/2018-03/Gender\%20Wilhite.pdf.

Zhou, Y. et al. 2018. System-level assessment of reliability and resilience provision from microgrids. Applied Energy. 230. pp. 374-392.

Zobair, S. 2019. Greening the Energy Sector of Bangladesh. ADB Conference on Inclusive Energy Resilience in Bangladesh. Gazipur, Bangladesh, 23 April 2019. 


\section{Inclusive Community Energy Resilience in Bangladesh}

This ADB South Asia working paper proposes a framework for mainstreaming gender equality and social inclusion (GESI) in energy system planning, establishes a methodology for measuring and comparing community and energy system resilience to extreme weather events, and clarifies how the proposed project design framework can be piloted in Bangladesh. The main contribution of this project design framework and methodology for a GESI-integrated resilient community energy system is its consideration of the technical and social aspects of energy resilience. It proposes to track sociodemographic indicators as key measures of power system performance. The study further proposes a risk-based approach to planning energy systems that would enhance community resilience to extreme weather events.

\section{About the Asian Development Bank}

ADB is committed to achieving a prosperous, inclusive, resilient, and sustainable Asia and the Pacific, while sustaining its efforts to eradicate extreme poverty. Established in 1966, it is owned by 68 members -49 from the region. Its main instruments for helping its developing member countries are policy dialogue, loans, equity investments, guarantees, grants, and technical assistance. 